\title{
Fish life-history traits are affected after chronic dietary exposure to an environmentally realistic marine mixture of PCBs and PBDEs
}

\author{
Horri Khaled ${ }^{1,7,{ }^{*}}$, Alfonso Sebastien ${ }^{2}$, Cousin Xavier ${ }^{3,4}$, Munschy Catherine ${ }^{5}$, Loizeau Veronique ${ }^{6}$, \\ Aroua Salima $^{7}$, Bégout Marie-Laure ${ }^{2}$, Ernande Bruno ${ }^{1}$
}

${ }^{1}$ Ifremer, Laboratoire Ressources Halieutiques, Centre Manche Mer du Nord, 150 quai Gambetta, F62200 Boulogne-sur-mer, France

2 Ifremer, Laboratoire Ressources Halieutiques, Station de La Rochelle, Place Gaby Coll, BP7, F-17137 L'Houmeau, France

${ }^{3}$ UMR MARBEC, IFREMER, IRD, UM2, CNRS, Laboratoire Adaptation et Adaptabilités des Animaux et des Systèmes, Route de Maguelone, F-34250 Palavas, France

${ }^{4}$ INRA, UMR GABI, INRA, AgroParisTech, Université Paris-Saclay, F-78350 Jouy-en-Josas, France

${ }^{5}$ Ifremer, Laboratoire Biogéochimie des Contaminants Organiques, Centre Atlantique, Rue de l'lle d'Yeu, BP 21105, F-44311 Nantes Cedex 3, France

${ }^{6}$ Ifremer, Laboratoire Biogéochimie des Contaminants Organiques, Centre Bretagne, ZI Pointe du

Diable, CS 10070, F-29280 Plouzané, France

${ }^{7}$ UMR-I 02 SEBIO, INERIS, URCA, ULH, Unité Stress Environnementaux et BIOsurveillance des milieux aquatiques, FR CNRS 3730 Scale, Université Le Havre Normandie, F-76063 Le Havre Cedex, France

*Corresponding author : Khaled Horri, email address : Khaled.Horri@ifremer.fr

\begin{abstract}
:
Polychlorinated biphenyls (PCBs) and polybrominated diphenyl ethers (PBDEs) are persistent organic pollutants that have been shown to affect fish life-history traits such as reproductive success, growth and survival. At the individual level, their toxicity and underlying mechanisms of action have been studied through experimental exposure. However, the number of experimental studies approaching marine environmental situations is scarce, i.e., in most cases, individuals are exposed to either single congeners, or single types of molecules, or high concentrations, so that results can hardly be transposed to natural populations. In the present study, we evaluated the effect of chronic dietary exposure to an environmentally realistic marine mixture of PCB and PBDE congeners on zebrafish lifehistory traits from larval to adult stage. Exposure was conducted through diet from the first meal and throughout the life cycle of the fish. The mixture was composed so as to approach environmentally relevant marine conditions in terms of both congener composition and concentrations. Life-history traits of exposed fish were compared to those of control individuals using several replicate populations in each treatment. We found evidence of slower body growth, but to a larger asymptotic length, and delayed spawning probability in exposed fish. In addition, offspring issued from early spawning events of exposed fish exhibited a lower larval survival under starvation condition. Given their strong dependency on life-history traits, marine fish population dynamics and associated fisheries productivity
\end{abstract}


for commercial species could be affected by such individual-level effects of PCBs and PBDEs on somatic growth, spawning probability and larval survival.

\section{Graphical abstract}
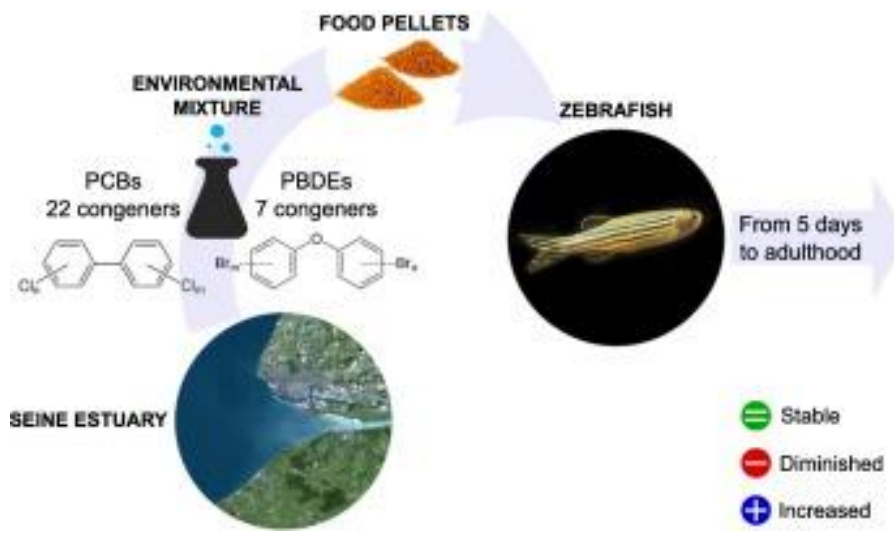

\begin{tabular}{|c|c|}
\hline LIFE-HISTORY TRAIT & EFFECT \\
\hline $\begin{array}{c}\text { Early and juvenile/adult F0 } \\
\text { survival }\end{array}$ & \\
\hline von Bertalantfy growth rate & \\
\hline Asymptotic length & \\
\hline Body condition & \\
\hline Spawning probability & \\
\hline Number of eggs & \\
\hline Fertilization rate & \\
\hline $\begin{array}{l}\text { Survival in unfed FI larvae: } \\
\text { early spawns }\end{array}$ & \\
\hline $\begin{array}{l}\text { Survival in unfed F1 larvae: } \\
\text { late spewns }\end{array}$ & $\theta$ \\
\hline
\end{tabular}

\section{Highlights}

- Effects of realistic marine PCB/PBDE mixtures on fish life-history are unknown. Zebrafish were chronically exposed to a realistic marine PCB/PBDE mixture via diet. Exposed fish grew to larger sizes but their spawning probability was delayed. Larval survival of offspring from early spawns was decreased under starvation. Environmental PCB/PBDE mixture can alter fish population dynamics via life-history.

Keywords : Contaminants, Body length, Condition, Fertilization rate, Energy allocation, Trade-off 


\section{Introduction}

Persistent organic pollutants (POPs) gather a wide number of chemicals which are of great concern because of their persistence, bioaccumulation and toxicity. In addition, given their propensity for long-range transport, they are globally distributed in various environments worldwide including some far from source areas (Bogdal et al., 2013; Corsolini, 2009; Rigét et al., 2016). Among POPs, polychlorinated biphenyls (PCBs) and polybrominated diphenyl ethers (PBDEs) are two families made of 209 congeners differing by the number and position of one to ten substitution by chlorine and bromine, respectively. PCBs have been used since the 1930s for various industrial purposes, such as dielectric fluids in electrical capacitors, transformers and hydraulic systems (United Nations Environment Programme, 1999), while PBDEs have been used since the 1970s as flame retardants in plastics, furniture, upholstery, electrical equipment, electronic devices, textiles and other household products (United Nations Environment Programme, 2012).

PCBs have been progressively banned in various countries since the 1970s whereas PBDEs have been banned or restricted more recently, beginning in the early 2000s. These regulations were endorsed internationally by the Stockholm Convention on POPs (United Nations Environment Programme, 2001). Today, only the commercial production of deca-PBDE is allowed, although with some restrictions in Europe. Although a decrease in their levels has been reported in biota from various locations (Byer et al., 2015; Rigét et al., 2016) and despite these restrictions, PCBs and PBDEs are still present in all environmental compartments worldwide, including aquatic ecosystems. Therefore they still represent a potential environmental concern. 
PCBs and PBDEs are found in the marine environment as complex mixtures of numerous congeners. Due to their long-term persistence and elevated lipophilicity (Mizukawa et al., 2009), they are significantly bioaccumulated and biomagnified through trophic transfer, in most biotic compartments of marine ecosystems (e.g. mollusks, fish, seals; Couderc et al., 2015; Johansson et al., 2006; Letcher et al., 2009). Such bioaccumulation could be a threat for animal communities and their population dynamics through the scaling up of their individuallevel effects to the population level (Vasseur and Cossu-Leguille, 2006). Notably, some scientists suspected that chemicals have contributed to the decline of some wild marine fish populations (Hamilton et al., 2015) and it has been suggested that the productivity of some marine fish stocks could be altered due to recruitment impairment caused by nursery habitat degradation in relation to pollutant accumulation (Gilliers et al., 2006; Riou et al., 2001; Rochette et al., 2010). Given the strong dependency of population dynamics on life-history (De Roos et al., 2003; Stearns, 1992), potential individual-level effects of PCBs and PBDEs on fish life-history traits could indeed affect fish population recruitment and dynamics and associated fisheries productivity for commercial species (Vasseur and Cossu-Leguille, 2006).

It is difficult, however, to ascertain the relationship between the presence of one class of chemical and its effects on biota from field observations, because of the accumulation of multiple potential stresses, including many families of chemicals, in natural environments (Baillon et al., 2016). In contrast, the experimental approach allows controlling for potential confounding effects and establishing such links without ambiguity. The effects and the underlying mechanisms of action of PCBs and PBDEs at the individual level have thus been intensively studied through experimental exposure, notably in fish. These studies have demonstrated an alteration of behavior, growth, reproductive, hepatic, and renal functions as well as of the immune and the endocrine systems in fish (Berg et al., 2011; Daouk et al., 2011; Han et al., 2011, 2013, Lyche et al., 2010, 2011; Muirhead et al., 2006; Péan et al., 
2013; Yu et al., 2015 and references therein). In particular, several studies have demonstrated that exposure of fish to either PCB or PBDE congener mixtures can affect fish life-history traits such as reproductive success, growth and survival. For example, it has been reported that long-term dietary exposure of zebrafish to a PCB mixture led to a decrease in the number of eggs per spawn and in their fertilization rate (Daouk et al., 2011). Furthermore, dietary exposure of fathead minnows to a single PBDE congener (BDE-47) was shown to reduce cumulative egg production (Muirhead et al., 2006), and McCarthy et al. (2003) showed that Atlantic croaker larvae originating from parents exposed to PCBs technical mixture (Aroclor 1254) through diet were characterized by diminished growth. In addition to their effects on reproductive success and growth, these compounds have been shown to increase fish earlylife-stage mortality. Indeed, it has been reported by Foekema et al. (2014) that exposure of common sole eggs to a mixture of POPs (including PCBs and PBDEs) via the water caused acute mortality in larvae after hatching. However, although experimental studies provide valuable information on the potential effects of PCBs and PBDEs, few have focused on environmental situations (see Berg et al., 2011; Lyche et al., 2010, 2011 for experiments mimicking freshwater lake environmental situations). In most cases, the exposure conditions are indeed quite different from environmental situations because of the use of either single congeners, or single types of molecules (i.e., PCBs, or PBDEs, or PAHs), or high concentrations and results can thus hardly be transposed to natural populations. How fish lifehistory traits may be affected by lifelong exposure to mixtures of both PCB and PBDE congeners that are realistic for the environment therefore remains largely unknown. More precisely, questions about the effects of environmentally realistic mixtures on growth, reproduction and survival and their consequences on individual fitness and population dynamics are still pending. 
119 In this study, we used the zebrafish model to explore the life-history effects associated with

120 long-term dietary exposure to a mixture of PCBs and PBDEs. Due to their lipophilicity, these

121 compounds are mostly found associated to organic matter and not in the water, so that dietary

122 exposure is considered the major route of exposure to PCBs and PBDEs for vertebrates (Muir

123 et al., 2003; Nyman et al., 2002). The selected congeners were chosen to approach

124 environmentally representative conditions for marine ecosystems in terms of both

125 concentrations and compositions. For PCBs, the mixture corresponded to the profile and

126 concentrations found in mussels from an estuary highly-impacted by industrial and urban

127 activities, the Seine estuary in France (Abarnou et al., 2000), which is a nursery area for many

128 flatfish species (Riou et al., 2001). Benthic invertebrates such as mussels are indeed an

129 important food source for many exploited fish species, notably flatfish and demersal fish. As

130 PBDEs profiles in living organisms depend upon their metabolism (Christensen et al., 2002;

131 Ma et al., 2013; Stapleton et al., 2004; Voorspoels et al., 2003), the mixture for this type of

132 molecules was not defined based on specific measurements, but corresponded to a mixture at

133 environmental concentration of the most representative congeners in marine biota and the

134 main congener in marine sediments that were identified for priority action by OSPAR

135 (OSPAR Commission, 2009, 2013).

136 These PCBs and PBDEs mixtures representative of environment situations were used for

137 identifying life-history effects potentially transposable to wild marine fish populations with

138 possible consequences for their population dynamics and productivity. Effects on early

139 survival, growth, reproduction and larval survival in the progeny were specifically

140 investigated. 


\section{Materials and methods}

142 This study was conducted under the approval of the Animal Care Committee of Poitou-

143 Charentes \# 84 COMETHEA (France) under project authorization number CE2012-23.

\section{$144 \quad 2.1 \quad$ Fish rearing}

145 Experiments were performed with wild type strain TU zebrafish (ZFIN ID: ZDBGENO146 990623-3) from a stock kept at the Fish Ecophysiology Platform (PEP 147 http://wwz.ifremer.fr/pep_eng) originating from the European Zebrafish Resources Center

148 (EZRC, Karlsruhe, Germany). Fish were maintained in heterosexual groups $(\mathrm{n}=28 \pm 5$

149 individuals per $10 \mathrm{~L}$-tank) under a $14 \mathrm{~h}$ day/10 h night light cycle. The resulting rearing 150 density fell within the recommended range of 1 to 5 individuals/L (Nüsslein-Volhard and 151 Dahm, 2002; Singleman and Holtzman, 2014). Water used in the rearing system was a 152 mixture of approximately $2 / 3$ reverse osmosis water and $1 / 3$ tap water, both being initially 153 treated by sediment and charcoal filters. Water physicochemical parameters were remained 154 constant during the experiment: temperature $27 \pm 1^{\circ} \mathrm{C}$, conductivity $300 \pm 50 \mu \mathrm{S} \mathrm{cm}^{-1}$ and pH $155 \quad 7.5 \pm 0.5$.

156 To produce the F0 generation, eggs were obtained by random pairwise mating of zebrafish 157 placed together in spawning boxes the evening before collection (AquaSchwarz, Germany). 158 Eggs from each clutch with a fertilization rate $>80 \%$ were collected the next morning in a

159 Petri dish containing $30 \mathrm{~mL}$ of isotonic mixture E3 (1 L: $17.2 \mathrm{~g} \mathrm{NaCl}, 0.76 \mathrm{~g} \mathrm{HCl}, 2.9 \mathrm{~g}$ $160 \mathrm{CaCl}_{2} .2 \mathrm{H}_{2} \mathrm{O}, 4.9 \mathrm{MgSO} 4.7 \mathrm{H}_{2} \mathrm{O}$ ) and placed at $28{ }^{\circ} \mathrm{C}$. Twenty four hours post-fertilization 161 (hpf), eggs from 5 clutches were mixed in a balanced way (taking the same number of eggs 162 from each clutch) and distributed in 20 Petri dishes at a rate of 60 larvae per Petri dish. The 20 163 groups of 60 larvae were considered together as one replicate population. At 5 days post 164 fertilization (dpf), the groups of 60 larvae were transferred from their Petri dishes to separate 
165 1-L tanks. At $15 \mathrm{dpf}$, the groups of larvae were transferred to tubes inserted inside separate

166 10-L rearing tanks disposed on flow-through racks and were then freed into the tanks at 27

167 dpf (after Vignet et al., 2014). In the flow-through racks, an hourly automated addition of 150

$168 \mathrm{~mL}$ of system water resulted in a daily total renewal of one third of the volume of each tank.

169 Discarded water was collected and treated with activated charcoal before being discharged

170 into sewers. Mesh bags filled with zeolite stones $(\sim 30 \mathrm{cL})$ were also added in each tank to

171 guarantee water quality. Tanks were inspected daily and cleaned by siphoning if necessary.

172 Furthermore, tanks were fully emptied and cleaned, together with zeolite bags, monthly from

173 the first biometry at 2 or 3 months age onwards. With this rearing protocol, concentrations of

174 ammonia, nitrites and nitrates measured were always below critical values for zebrafish

175 (Lawrence, 2007) and even below quantification level in most cases.

176 Fish were fed three times per day, twice with pellets in the morning and the evening, and once

177 with freshly hatched crustaceans (Artemia salina) at noon. Food pellet size was adapted to 178 fish's mouth size using their age as a proxy. From 5 to $60 \mathrm{dpf}$, fish were fed sequentially with

179100,200 and $300 \mu$ m SDS (Special Diet Service; Dietex international, United Kingdom) with

1805 to 10 days of overlap; from 60 to $70 \mathrm{dpf}$, fish were fed with a mixture of $300 \mu \mathrm{m}$ SDS and

181 Inicio $^{+} 500 \mu \mathrm{m}$ (Biomar, France), and from $70 \mathrm{dpf}$ onwards, they were fed with Inicio ${ }^{+}$ $182500 \mu \mathrm{m}$ only.

\section{$183 \quad 2.2 \quad$ Fish exposure}

184 Fish were exposed to contaminants through food pellets spiked with a mixture of PCB and

185 PBDE congeners following the food-pellet size depending on age sequence presented above.

186 The spiking procedure was similar for all pellet sizes except for vessel and solution volumes

187 that were of course adapted to the quantity of food to be spiked. PCB and PBDE congeners 
used in contaminated diet and their concentrations were chosen in order to represent

189 environmental conditions.

190 For PCBs, the choice was based on the contamination levels and profiles reported in mussels

191 from the Seine estuary, one of the most contaminated site along the French coastlines

192 (Abarnou et al., 2000). This choice was justified by the fact that many exploited fish species,

193 especially flatfish (e.g. sole, plaice, turbot) and demersal fish (e.g. cod, haddock, seabass),

194 feed largely on benthic invertebrates and/or have nursery grounds in industrialized estuaries.

195 More precisely, contaminated food was spiked with a mixture of 22 PCB congeners, i.e.,

196 congeners CB-8, CB-18, CB-28, CB-31, CB-44, CB-49, CB-52, CB-77, CB-101, CB-105,

197 CB-110, CB-118, CB-128, CB-132, CB-138, CB-149, CB-153, CB-156, CB-170, CB-180,

198 CB-187 and CB-194 at targeted concentrations between 28 and $280 \mathrm{ng} \mathrm{g}^{-1}$ ww (wet weight)

199 per congener. The 22 congeners used covered a wide range of chlorinated substitutions (2-8)

200 and a range of hydrophobicity ( $\log \mathrm{K}_{\mathrm{ow}}$ - octanol/water partition coefficient) from 5.07 to 7.80

201 (Hawker and Connell, 1988).

202 For PBDEs, targeted contamination levels and profiles were based on the 6 most 203 representative congeners in marine biota and the main congener in marine sediments that were 204 identified for priority action by OSPAR (OSPAR Commission, 2009, 2013). The rationale for 205 this choice is that PBDE congeners are metabolized more easily and quickly than PCB 206 congeners in low trophic level marine organisms (Grimm et al., 2015; Zhang et al., 2016). As 207 a result, the PBDE congener profiles found in an organism's tissue will depend on the species 208 considered as PBDE metabolism varies between species. It follows that we did not want to 209 define the target profile of PBDE congeners based on measurements on a particular species. 210 More specifically, contaminated food was also spiked with a mixture of 7 PBDE congeners, 211 i.e., congeners BDE-28, BDE-47, BDE-99, BDE-100, BDE-153, BDE-183 for marine biota 212 and congener BDE-209 for marine sediments at targeted concentrations of between 10 and 
$213200 \mathrm{ng} \mathrm{g}^{-1} \mathrm{ww}$ per congener. The reason why BDE-209 was included is that, despite the fact it

214 is not listed among the main congeners in marine biota in general as it disappears at high

215 trophic levels (Burd et al., 2014) and in pelagic biota (Desforges et al., 2014), it is the main

216 PBDE congener found in marine sediments and thus one of the main in benthic invertebrates

217 (together with BDE-47, BDE-99 and BDE-100; Burd et al., 2014; Dinn et al., 2012). As

218 explained previously, many exploited fish are benthic or demersal species feeding largely on

219 benthic invertebrates, so that it was sensible to include BDE-209 in the mixture tested. The 7

220 congeners used covered a wide range of brominated substitutions (3 - 10) and a range of

221 hydrophobicity $\left(\log \mathrm{K}_{\mathrm{ow}}\right.$ ) from 6.7 to 12.1 (Kelly et al., 2008).

222 The precise targeted and measured concentrations for each PCB and PBDE congener are 223 available in Table S1. The contaminated diet was prepared after dilution of a stock PCB and 224 PBDE solution in isooctane solvent for incorporation as described in Daouk et al. (2011). The 225 control diet was prepared in the same manner, i.e., with isooctane solvent but without addition of POPs. Control and contaminated diets were prepared with food of all sizes.

227 Fish were fed from their first meal $(5 \mathrm{dpf})$ with either a control diet or a contaminated diet 228 using the feeding schedule described earlier. A total of 5 replicate populations, each 229 composed of $9 \pm 1$ tanks per dietary treatment (46 tanks per treatment in total, see Table S3 230 for details), were used in this study to increase the significance and confidence level of the 231 experimental results. Hereafter, we will refer to fish exposed to the control and the contaminated diet as SOLV (as solvent) and MIX (as mixture) fish, respectively.

\subsection{PCB and PBDE analyses}

234 PCBs and PBDEs were analyzed in all batches of MIX $(\mathrm{n}=12)$ and SOLV diets $(\mathrm{n}=16)$, and 235 in MIX (PCBs: $\mathrm{n}_{\text {females }}=\mathrm{n}_{\text {males }}=3$; PBDEs: $\mathrm{n}_{\text {females }}=\mathrm{n}_{\text {males }}=3$ ) and SOLV fish (PCBs: $\mathrm{n}_{\text {females }}$ $236=\mathrm{n}_{\text {males }}=1$; PBDEs: $\mathrm{n}_{\text {females }}=\mathrm{n}_{\text {males }}=3$ ) at $180 \mathrm{dpf}$ using the methods described in Daouk et 
al. (2011) and Munschy et al. (2011), respectively. Briefly, PCBs were extracted using a hot

238 Soxhlet apparatus (Soxtec), purified sequentially with concentrated sulfuric acid and by 239 adsorption chromatography on Florisil column, and analyzed using gas chromatography 240 equipped with an electron capture detector (GC- $\mu \mathrm{ECD})$. PBDEs were analyzed using 241 Accelerated Solvent Extraction (ASE, Dionex Corp., USA) followed by gel permeation 242 chromatography, silica and alumina column, and concentrated sulfuric acid treatment prior to 243 quantification by gas chromatography coupled to mass spectrometry (GC-MS) in electron capture negative ionisation mode (ECNI). Analyses on fish were done on entire individuals.

\subsection{Quality assurance/quality control}

\subsubsection{PCB analysis}

247 The calibration of the system was performed within a large range using a multi-point (6)

248 calibration curve to define the linearity range of our detector (ECD) for all contaminants. The 249 relative precision of the method was checked for this type of samples by the analysis of 6 250 aliquots of a homogeneous preparation of fish (laboratory control card). The results showed 251 coefficients of variation of $<10 \%$ for all congeners, which indicates a satisfactory 252 reproducibility of the method. Detailed information is provided in Supplementary Text S2.

\subsubsection{PBDE analysis}

254 Quality Assurance / quality Control procedures were implemented for each batch of 8 to 10 255 samples, including procedural blanks, use of recovery surrogates in all samples, analysis of 256 certified reference material and participation to inter-comparison exercises. Detailed 257 information can be found in Munschy et al. (2011) and an update is provided in 258 Supplementary Text S2. 


\subsection{Trait monitoring}

260 The following description covers trait monitoring of all replicates at once while some details 261 (number of tanks, precise date of biometries, etc.) may vary between replicates. Such details 262 are given in supplementary Table S3 and corresponding variation is indicated as standard 263 deviation or minimum and maximum values in the main text below.

\subsubsection{Survival}

265 Early survival of individuals was followed by counting daily the number of live fish in each 266 tank of each replicate from $5 \mathrm{dpf}$ to the juvenile stage $(30 \pm 6 \mathrm{dpf}$, mean $\pm \mathrm{SD}$; see date for 267 each replicate in Table S3) for all replicates.

268 Juvenile/adult survival was monitored monthly from $30 \pm 6$ dpf to $183 \pm 4$ dpf for all replicates 269 on the occasion of growth monitoring (see below for growth monitoring and Table S3 for 270 precise dates of biometries). As individuals were sampled from various tanks within each

271 replicate during this period for additional analyses but without keeping the information of the 272 tanks sampled, data had to be aggregated at the replicate level.

\section{$273 \quad$ 2.5.2 Growth}

274 Growth of all fish was monitored monthly from $65 \pm 10 \mathrm{dpf}$ to between 181 and $362 \mathrm{dpf}$ 275 depending on the replicate (see dates for each replicate in Table S3). On each occasion, 276 individual standard length $(\mathrm{mm})$ and body weight $(\mathrm{g})$ were measured after anesthesia with 277 benzocaine (Vignet et al., 2014). Sex was determined whenever possible based on 278 morphological clues, generally from around 3 months old onwards. All replicates were used 279 for this monitoring. 


\subsubsection{Reproduction test}

281 After $72 \pm 11 \mathrm{dpf}$, reproduction was monitored for $17 \pm 7$ days by placing two spawning 282 boxes into each rearing tank (see dates for each replicate in Table S3). Eggs were collected 283 the next morning and sorted to count the total number of eggs as well as the number of 284 fertilized ones. The fertilization rate was then calculated for each spawning event. The total 285 number of spawning events obtained relative to solicitation number (equal to the number of 286 inspected rearing tanks per treatment) was calculated for each treatment and replicate. For 287 each tank, sex-ratio $s$, mean individual food consumption $c$, number of individuals $N$, 288 length of females $l_{f}$, and length of males $l_{m}$ were measured and the age $a$ of fish was 289 recorded. In this test, the length of both males and females from each tank was measured on 290 day $30 \pm 18$ (depending on the replicate) only to avoid repetitive stress during the test. 291 Reproduction monitoring was very time-consuming and due to manpower limitations only a 292 selection of replicates (1,2 and 4, 28 tanks in total per treatment) was used for this 293 assessment.

\subsubsection{Larval survival in the progeny}

295 A survival experiment was performed on unfed F1 larvae of replicate 4. The purpose of this experiment was to determine whether the exposure of parents (F0) to $\mathrm{PCB}$ and $\mathrm{PBDE}$ congeners could affect the survival of their offspring larvae (F1).

298 Survival of unfed larvae was monitored on two occasions corresponding to the $1^{\text {st }}$ and $10^{\text {th }}$ 299 spawning events of F0 fish. On each occasion, survival was studied on 3 different clutches 300 from 10 rearing tanks per dietary treatment. Thirty eggs were collected from each clutch and 301 kept in a Petri dish in $30 \mathrm{~mL}$ of E3 medium at $28^{\circ} \mathrm{C}$ until the end of the survival experiment. 
302 In total, the survival of 900 larvae per treatment and spawning event $\left(1^{\text {st }}\right.$ and $\left.10^{\text {th }}\right)$ was

303 monitored $(n=30$ eggs $\times 3$ clutches $\times 10$ tanks $\times 2$ treatments $\times 2$ dates $=3600$ larvae $)$.

304

305

306

307

308

309

310

311

312

313

314

315

\subsection{Statistical analyses}

\subsubsection{Modeling approach}

Statistical analyses were performed in R version 3.2.2 (R Development Core Team, 2015). All traits were analyzed using mixed-effects models. Random effects were used to account for variability due to rearing tanks and/or replication depending on the trait considered: two nested random effects, namely replicates and tanks nested within replicates (replicate/tank), were included in models describing F0 generation traits, except for juvenile/adult survival for which only replicates were included due to data aggregation, and clutches nested within tanks were included in the model describing unfed F1 larvae survival. Random effects affected either the model intercept only or both model intercept and slopes. For each trait, the fixed part of the model included a dietary treatment effect ( $T$, MIX versus SOLV diet) to assess the effect of fish exposure to the mixture of PCBs and PBDEs plus relevant covariates likely to biologically affect the considered trait (see description below for each trait as well as Table S4 for details on fixed and random effects).

For each trait, the full model was reduced by backward selection in two steps: the random part of the model was reduced first and the fixed part was selected afterwards (Pinheiro and Bates, 2000; Zuur et al., 2009). Selection was based on significance of the effects at a 5\% alpha risk threshold determined by likelihood ratio tests (LRT) between nested models while respecting the marginality of the effects. Such LRTs are supposed to follow a $\chi^{2}$ distribution under the null hypothesis (type II tests; Fox and Weisberg, 2011). Diagnostics based on residuals were used to assess the adequacy of the reduced model and compliance to the underlying 
assumptions. Variables were transformed whenever necessary to ensure that the residuals

326 followed the assumed error distribution (Table S4). Finally, the effects of treatment $T$ and

327 other active covariates were estimated from the reduced models and their significance was

328 tested by LRT. When the reduced models did not include the treatment effect $T$, the test

329 provided for this effect corresponds to the LRT test during the selection procedure. Only the

330 fixed part of the selected models will be presented in the Results section. Random effects are

331 mere technical parameters included to account for variation due to tanks and replication and

332 thus to obtain robust estimates and significance tests of fixed effects against such variation.

333 Therefore, detailed information on the random part is given in Table S5 in Supplementary

334 Material.

335 In the following sections, we describe how the fixed part of the full model was defined for 336 each trait.

\section{$337 \quad$ 2.6.2 Survival}

338 Time to death at early and juvenile/adult stages was modeled using survival analysis

339 (Therneau and Grambsch, 2000) as the data analyzed here are right-censored data because

340 some individuals were still alive at intermediate sampling dates (individuals sampled for

341 additional analyses) and at the end of the study. More precisely, two mixed-effects Cox

342 proportional hazards models (COXME) were used to estimate how the hazard rate, i.e., the

343 death rate, was affected by the contamination treatment $T$ as a fixed effect (Table S4) during

344 early and juvenile/adult stages. Cox models allow the death rate to be modeled as being

345 affected proportionally (i.e., multiplicatively) by the explanatory variables. In practice, a

346 logarithmic link function is used to allow for a linear predictor of the death rate. The COXME

347 models were implemented using the coxme package in $\mathrm{R}$ (Therneau, 2015). 


\subsubsection{Growth}

349 Fish growth was modeled according to the Von Bertalanffy growth (VBG) function using a 350 non-linear mixed-effects model (NLME; Pinheiro and Bates, 2000). The VBG equation 351 describes fish length $l(a)(\mathrm{mm})$ according to individual age $a$ (days) as

$$
l(a)=l_{\infty}-\left(l_{\infty}-l_{0}\right) e^{-k\left(a-a_{0}\right)}
$$

where $l_{\infty}$ is the asymptotic standard length $(\mathrm{mm}), l_{0}$ is the initial standard length $(\mathrm{mm})$ at age

$354 a_{0}$ (days), $a_{0}$ is the age at the first biometric measurement and $k$ is the growth rate 355 coefficient $\left(\right.$ day $\left.^{-1}\right)$. To ensure well-behaved residuals of the fitted model, the VBG function to 356 the power of 3 was fitted to length data to the power of 3 . This is because the VBG function 357 was initially developed to describe growth in mass and that individual mass is roughly 358 proportional to individual length to the power of 3 (Von Bertalanffy, 1938).

359 Nested within the VBG function, the three parameters of this model, $l_{0}, l_{\infty}$, and $k$ were 360 themselves modeled as depending linearly on fixed effects, namely treatment $T$ only for $l_{0}$, 361 and treatment $T$, individual's sex $S$ and their interaction for $l_{\infty}$ and $k$, as well as on random 362 effects (replicate/tank; Table S4). $l_{0}$ was not modeled as dependent on sex as no sexual 363 length dimorphism was observed at age $a_{0}$. The NLME model was implemented using the 364 nlme package in $\mathrm{R}$ (Pinheiro et al., 2016).

\subsubsection{Condition}

366 Fish condition, defined as length-specific weight, was modeled via the length-weight 367 allometry $W=a l^{b}$ linearized by log-transformation (Froese, 2006): 


$$
\log W=\log a+b \log l
$$

where $W$ is wet weight $(\mathrm{g}), l$ is standard length $(\mathrm{mm}), \log a$ is the regression intercept and $b$ is the regression slope. A linear mixed-effects model (LME) was used to analyze how treatment $T$, individual's sex $S$ and their interaction taken as fixed effects modified this relationship (Table S4). The LME model was fitted using the nlme package in $\mathrm{R}$ (Pinheiro et al., 2016).

\subsubsection{Spawning probability}

A generalized linear mixed-effects model (GLMM) with binomial error distribution and logit link function was used to analyze the effect of PCBs and PBDEs exposure on spawning probability based on the number of spawning events relative to solicitation number in reproduction tests (i.e., the number of trials to obtain a spawn). Fixed effects included treatment $T$, but also age $a$ to assess how spawning probability increased with age, plus their interaction, as well as the mean length of females $\bar{l}_{f}$, the mean length of males $\bar{l}_{m}$, and the mean individual food consumption $c$ in the rearing tank as covariates (Table S4). In this analysis, all continuous explanatory variables were standardized, i.e., centered and scaled to unit variance. The GLMM model was fitted using the lme4 package in R (Bates et al., 2015).

\subsubsection{Number of eggs}

To test whether PCB and PBDE congener mixtures affect reproductive output, the number of eggs produced by each rearing tank during reproduction tests was modeled using an LME model. The fixed effects included in the full-model were treatment $T$, age $a$ (as clutch size often increases with age in fish), their interaction, plus the mean individual food consumption $c$, the number of individuals $N$, and the sex-ratio $s$ in the rearing tank as covariates (Table S4). A Box-Cox transformation was applied to the response variable (eggs number) to obtain 
a normal distribution of the residuals and all continuous explanatory variables were

392 standardized. The LME model was fitted using the nlme package in R (Pinheiro et al., 2016).

393

394

395

396

\subsubsection{Fertilization rate}

Fertilization rate, obtained as the number of fertilized eggs relative to the total number of eggs in each rearing tank during reproduction tests was analyzed in the same way as spawning probability (see description above).

\subsubsection{Larval survival in the progeny}

As for early survival of the F0 generation, survival of unfed F1 larvae was analyzed using a COXME model. In this case, data were uncensored data as all individuals were dead at the end of the experiment. The fixed effects included treatment $T$, occasion $O\left(1^{\text {st }}\right.$ and $10^{\text {th }}$ F0 spawning event) and their interaction.

\section{Results}

\subsection{PCB and PBDE concentrations in diet and fish}

PCB and PBDE concentrations in MIX and SOLV diets are presented in Table S1. In MIX diet $(\mathrm{n}=12)$, the total concentrations, i.e., summed across congeners, were $1932.3 \pm 90.4 \mathrm{ng}$ $\mathrm{g}^{-1}$ ww for PCBs and $479.8 \pm 50.8 \mathrm{ng} \mathrm{g}^{-1}$ ww for PBDEs. In SOLV diet $(\mathrm{n}=16)$, the total concentrations were circa 245 and 522 times lower, i.e., $7.9 \pm 3.5 \mathrm{ng} \mathrm{g}^{-1} \mathrm{ww}$ for PCBs and $0.92 \pm 0.36 \mathrm{ng} \mathrm{g}^{-1} \mathrm{ww}$ for PBDEs.

In MIX fish, the total concentrations of PCBs $(n=3)$ and PBDEs $(n=3)$ at $180 \mathrm{dpf}$ in entire individuals were respectively $2188.3 \pm 132.26$ and $110.9 \pm 1.14 \mathrm{ng} \mathrm{g}^{-1}$ ww in females, and $2140 \pm 73.95$ and $96.4 \pm 8.65 \mathrm{ng} \mathrm{g}^{-1}$ ww in males. In SOLV fish, the total concentrations of 
412 PCBs $(\mathrm{n}=1)$ and PBDEs $(\mathrm{n}=3)$ at $180 \mathrm{dpf}$ were respectively 26.2 and $1.1 \pm 0.31 \mathrm{ng} \mathrm{g}^{-1} \mathrm{ww}$ 413 in females, and 26.7 and $2.7 \pm 0.54 \mathrm{ng} \mathrm{g}^{-1} \mathrm{ww}$ in males.

\section{$414 \quad 3.2$ Survival}

415 Early survival probabilities at the end of the survival experiment ( $30 \pm 6 \mathrm{dpf})$ ranged from $41647 \%$ to $89 \%$ and from $51 \%$ to $87 \%$ in MIX and SOLV fish, respectively (Kaplan-Meier 417 curve; Fig. 1). Juvenile/adult survival probabilities at $183 \pm 4 \mathrm{dpf}$ ranged from $44 \%$ to $73 \%$ 418 and from $38 \%$ to $70 \%$ in MIX and SOLV fish, respectively (Kaplan-Meier curve; Fig. 2). No 419 significant effect of the treatment on both early and juvenile/adult death rate was detected ( $T$ 420 effect Table 1; Fig. 1; Fig. 2).

421 


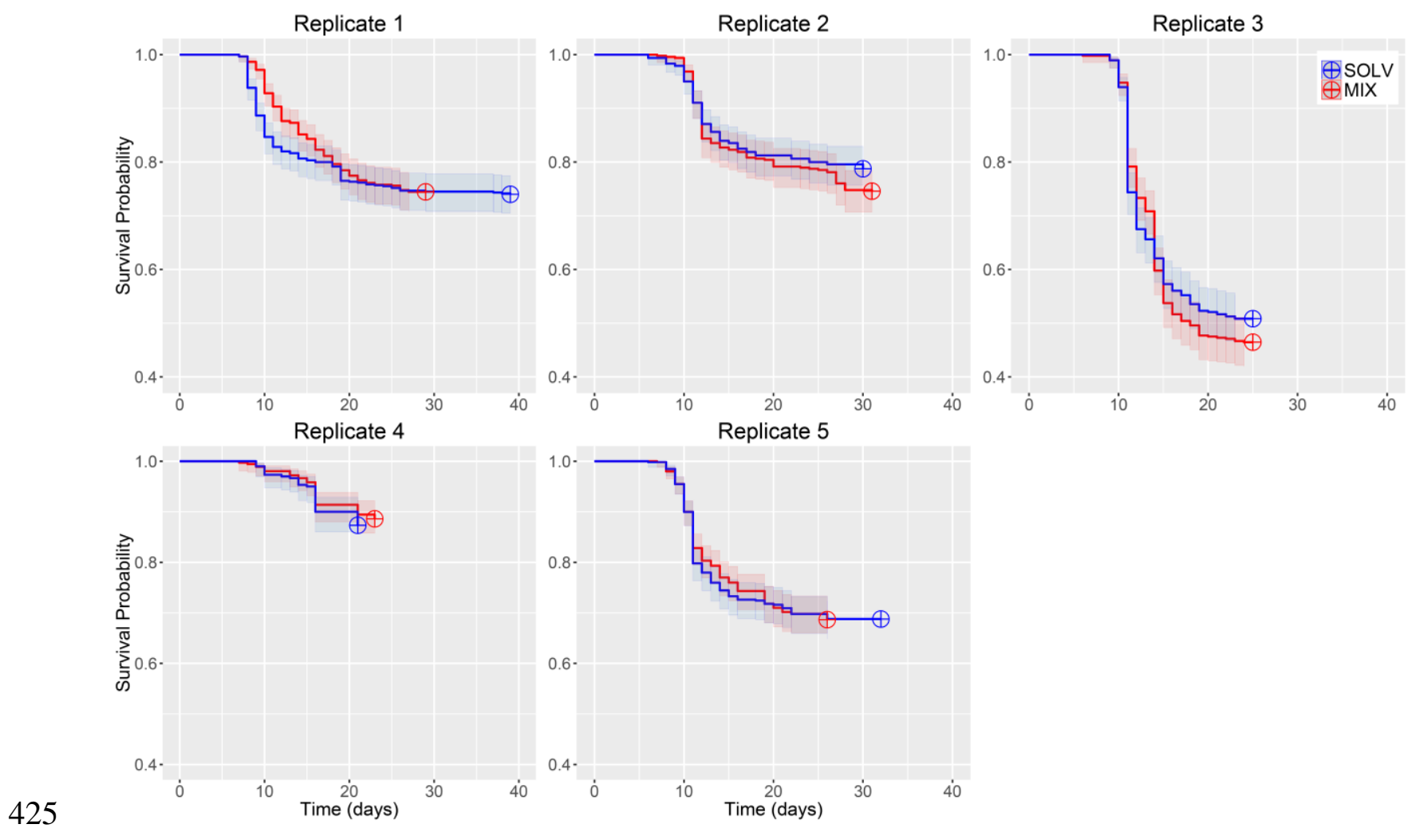

Fig. 1. Effect of dietary exposure to a PCB and PBDE congeners mixture on the early death rate of zebrafish. Curves represent the estimated decrease in individuals' survival probability with time by Kaplan-Meier estimator for MIX (red) and SOLV (blue) treatment, respectively, and shaded areas are the corresponding confidence intervals. 


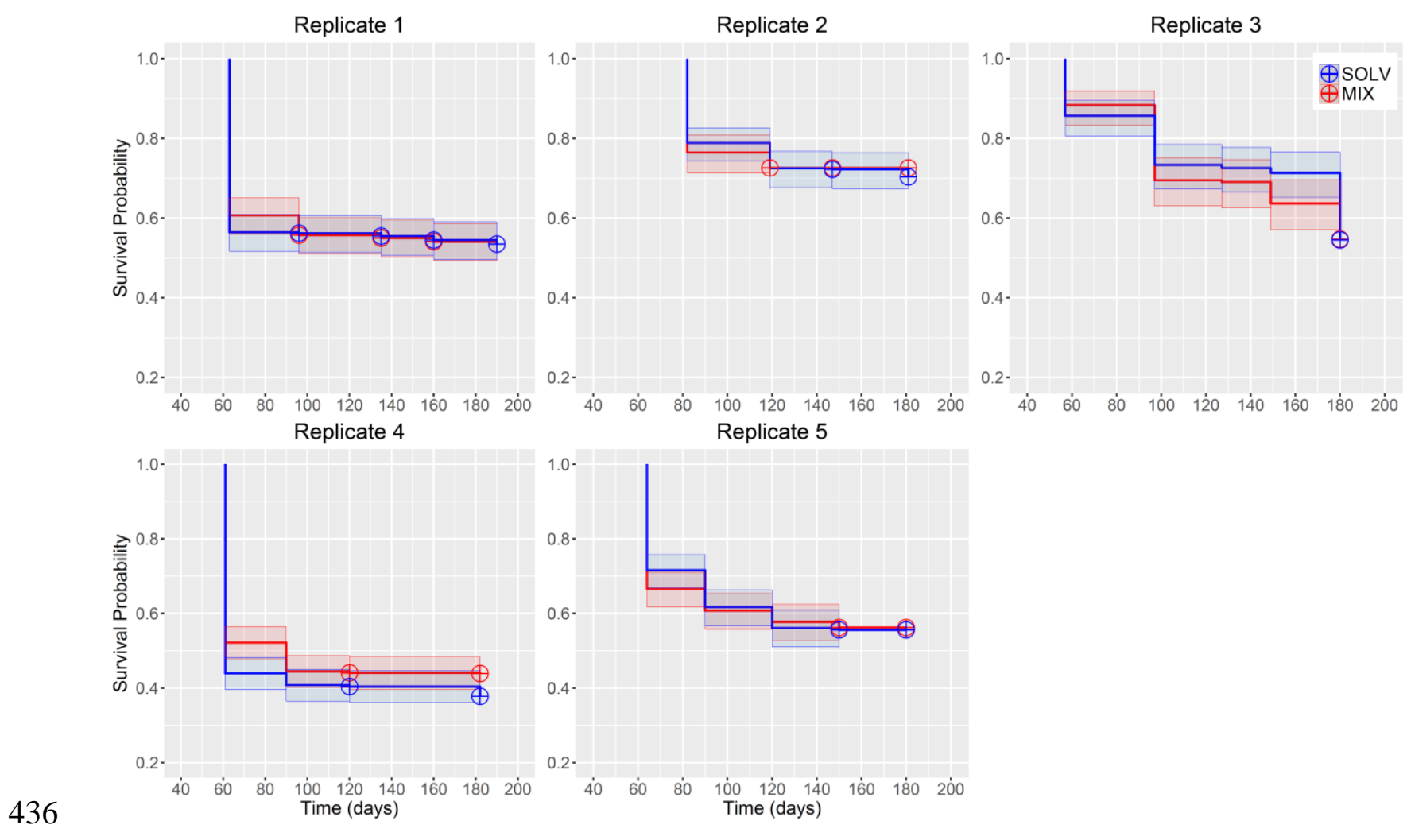

437 Fig. 2. Effect of dietary exposure to a PCB and PBDE congeners mixture on the juvenile and adult death rate of 438 zebrafish. Curves represent the estimated decrease in individuals' survival probability with time by Kaplan439 Meier estimator for MIX (red) and SOLV (blue) treatment, respectively, and shaded areas are the corresponding 440 confidence intervals. 
Table 1. Results of mixed-effects models testing for the effects of dietary treatment (MIX vs. SOLV) and other explanatory variables on the life-history traits of zebrafish. For categorical variables, effects are estimated for one category (indicated between parentheses) relative to the reference one taken as the intercept, namely MIX relative to SOLV for treatment $T$, and males $\mathrm{M}$ relative to females $\mathrm{F}$ for sex $S$.

\begin{tabular}{|c|c|c|c|c|c|c|c|}
\hline Function & Trait & Effect & Estimate & s.e. & $d f$ & $\chi^{2}$ & p-value \\
\hline Survival & $\begin{array}{l}\text { Early death } \\
\text { rate }\end{array}$ & $\begin{array}{l}\text { baseline hazard (SOLV) } \\
T \text { (MIX) }\end{array}$ & $\begin{array}{l}\text { n.a. } \\
0.034\end{array}$ & $\begin{array}{l}\text { n.a. } \\
0.072\end{array}$ & $\begin{array}{l}\text { n.a. } \\
1\end{array}$ & $\begin{array}{l}\text { n.a. } \\
0.23\end{array}$ & $\begin{array}{l}\text { n.a. } \\
0.631\end{array}$ \\
\hline Survival & $\begin{array}{l}\text { Juvenile/adult } \\
\text { death rate }\end{array}$ & $\begin{array}{l}\text { baseline hazard (SOLV) } \\
T \text { (MIX) }\end{array}$ & $\begin{array}{l}\text { n.a. } \\
-0.087\end{array}$ & $\begin{array}{l}\text { n.a. } \\
0.048\end{array}$ & $\begin{array}{l}\text { n.a. } \\
1\end{array}$ & $\begin{array}{l}\text { n.a. } \\
3.29\end{array}$ & $\begin{array}{l}\text { n.a. } \\
0.070\end{array}$ \\
\hline Growth & $l_{0}$ & $\begin{array}{l}\text { intercept (SOLV) } \\
T \text { (MIX) }\end{array}$ & $\begin{array}{l}2.946 \\
0.019\end{array}$ & $\begin{array}{l}0.024 \\
0.016\end{array}$ & $\begin{array}{l}\text { n.a. } \\
1\end{array}$ & $\begin{array}{l}\text { n.a. } \\
1.97\end{array}$ & $\begin{array}{l}\text { n.a. } \\
0.160\end{array}$ \\
\hline Growth & $k$ & $\begin{array}{l}\text { intercept (F/SOLV) } \\
S \text { (M) } \\
T \text { (MIX) }\end{array}$ & $\begin{array}{l}-4.317 \\
0.112 \\
-0.141\end{array}$ & $\begin{array}{l}0.119 \\
0.027 \\
0.047\end{array}$ & $\begin{array}{l}\text { n.a. } \\
1 \\
1\end{array}$ & $\begin{array}{l}\text { n.a. } \\
19.56 \\
6.40\end{array}$ & $\begin{array}{l}\text { n.a. } \\
<0.001 \\
0.011\end{array}$ \\
\hline Growth & $l_{\infty}$ & $\begin{array}{l}\text { intercept (F/SOLV) } \\
S \text { (M) } \\
T \text { (MIX) }\end{array}$ & $\begin{array}{l}3.527 \\
-0.067 \\
0.024\end{array}$ & $\begin{array}{l}0.005 \\
0.005 \\
0.006\end{array}$ & $\begin{array}{l}\text { n.a. } \\
1 \\
1\end{array}$ & $\begin{array}{l}\text { n.a. } \\
171.52 \\
11.35\end{array}$ & $\begin{array}{l}\text { n.a. } \\
<0.001 \\
<0.001\end{array}$ \\
\hline Condition & $W$ & $\begin{array}{l}\text { Intercept (F/SOLV) } \\
\log (l) \\
S \text { (M) } \\
T \text { (MIX) }\end{array}$ & $\begin{array}{l}-11.573 \\
3.247 \\
-0.165 \\
-0.010\end{array}$ & $\begin{array}{l}0.040 \\
0.008 \\
0.003 \\
0.008\end{array}$ & $\begin{array}{l}\text { n.a. } \\
1 \\
1 \\
1\end{array}$ & $\begin{array}{l}\text { n.a. } \\
29057.02 \\
2219.74 \\
1.84\end{array}$ & $\begin{array}{l}\text { n.a. } \\
<\mathbf{0 . 0 0 1} \\
<\mathbf{0 . 0 0 1} \\
0.175\end{array}$ \\
\hline Reproduction & Spawning & $\begin{array}{l}\text { intercept (SOLV) } \\
a \\
\bar{l}_{f}\end{array}$ & $\begin{array}{l}0.829 \\
2.033 \\
-0.746\end{array}$ & $\begin{array}{l}0.238 \\
0.248 \\
0.228\end{array}$ & $\begin{array}{l}\text { n.a. } \\
1 \\
1\end{array}$ & $\begin{array}{l}\text { n.a. } \\
127.21 \\
10.70\end{array}$ & $\begin{array}{l}\text { n.a. } \\
<0.001 \\
0.001\end{array}$ \\
\hline & probability & $\begin{array}{l}\bar{l}_{m} \\
T(\mathrm{MIX}) \\
T \times a\end{array}$ & $\begin{array}{l}0.600 \\
-0.464 \\
-0.924\end{array}$ & $\begin{array}{l}0.287 \\
0.275\end{array}$ & $\begin{array}{l}1 \\
1\end{array}$ & $\begin{array}{l}1.30 \\
11.30\end{array}$ & $\begin{array}{l}0.253 \\
<0.001\end{array}$ \\
\hline Reproduction & $\begin{array}{l}\text { Number of } \\
\text { eggs }\end{array}$ & $\begin{array}{l}\text { intercept (SOLV) } \\
a \\
N \\
T \text { (MIX) }\end{array}$ & $\begin{array}{l}10.022 \\
1.409 \\
-0.646 \\
-0.486\end{array}$ & $\begin{array}{l}0.294 \\
0.166 \\
0.193 \\
0.403\end{array}$ & $\begin{array}{l}\text { n.a. } \\
1 \\
1 \\
1\end{array}$ & $\begin{array}{l}\text { n.a. } \\
72.21 \\
11.29 \\
1.46\end{array}$ & $\begin{array}{l}\text { n.a. } \\
<\mathbf{0 . 0 0 1} \\
<\mathbf{0 . 0 0 1} \\
0.227\end{array}$ \\
\hline Reproduction & $\begin{array}{l}\text { Fertilization } \\
\text { rate }\end{array}$ & $\begin{array}{l}\text { intercept (SOLV) } \\
a \\
T \text { (MIX) }\end{array}$ & $\begin{array}{l}-0.175 \\
0.978 \\
0.041\end{array}$ & $\begin{array}{l}1.246 \\
0.478 \\
0.346\end{array}$ & $\begin{array}{l}\text { n.a. } \\
1 \\
1\end{array}$ & $\begin{array}{l}\text { n.a. } \\
4.19 \\
0.014 \\
\end{array}$ & $\begin{array}{l}\text { n.a. } \\
<\mathbf{0 . 0 4 1} \\
0.906\end{array}$ \\
\hline
\end{tabular}

$460 \quad$ p-values $<0.05$ are in bold.

\section{$461 \quad 3.3 \quad$ Growth}

462 Growth data revealed sexual length dimorphism, females being larger than males, and 463 suggested that MIX fish grew to larger lengths than SOLV fish (Fig. 3). These observations 464 were confirmed by the VBG model. Males grew at a faster rate $k$ than females but to smaller 465 asymptotic length $l_{\infty}$ ( $S$ effect on both parameters, Table 1). More importantly, the VBG 466 model showed that MIX fish grew at slower rate $k$ ( $-13.00 \%$ for MIX individuals relative to 
467 SOLV ones; $T$ effect on parameter $k$, Table 1) but to larger asymptotic length $l_{\infty}$ than SOLV 468 fish (+2.40\% for MIX individuals relative to SOLV ones; $T$ effect on $l_{\infty}$, Table 1$)$ and that 469 these effects were independent of sex (no significant $T \times S$ interaction was found and it was 470 therefore not kept in the model). In contrast, no significant effect of the treatment was 471 observed on initial length $l_{0}$ ( $T$ effect, Table 1), which is the length at first biometric 472 measurement.

\section{$473 \quad 3.4$ Condition}

474 The length-weight relationship differed significantly across sexes (main $S$ effect, Table 1; 475 Fig. 4), males being lighter than females at equivalent length (- $15.23 \%$ of weight difference 476 at 16, 24 and $32 \mathrm{~mm}$ for males). In contrast, there was no significant difference between MIX 477 and SOLV fish, indicating that exposure had no effect on fish condition (main $T$ effect, Table 478 1; Fig. 4). Moreover, the absence of interactions between $\log (l)$ and both $S$ and $T$ in the 479 reduced model indicated that the shape of the allometric relationship between length and 480 weight, determined by the exponent $b=3.247(\log (l)$ effect, Table 1$)$, was unaffected by 481 sex or treatment (Fig. 4).

482 483 484 485 


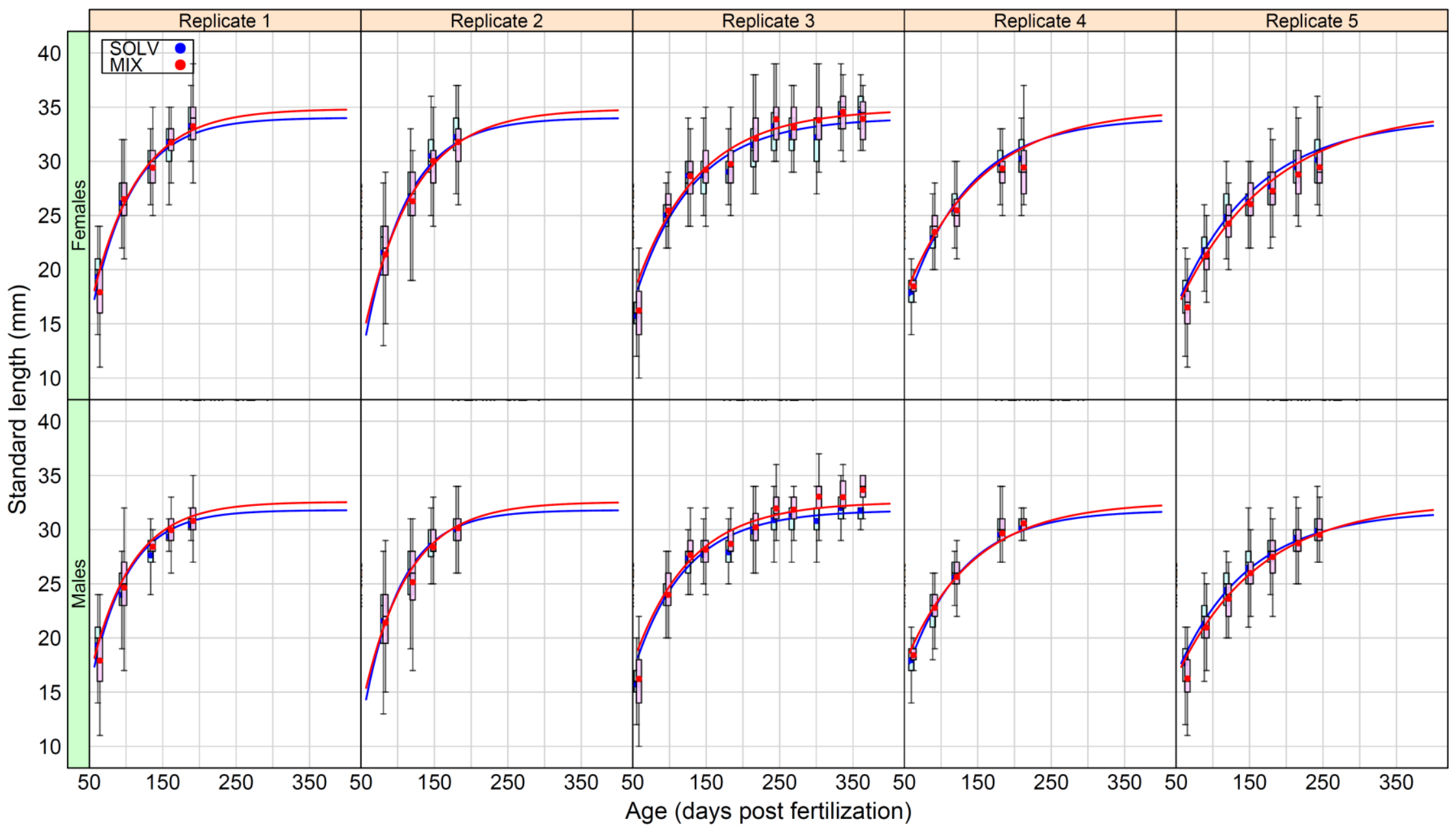

Fig. 3. Effect of dietary exposure to a PCB and PBDE congeners mixture on growth (in terms of standard length) in zebrafish. Rows correspond to the sex of fish and columns to the replicates. Boxplots represent observations per treatment (MIX in red and SOLV in blue) and curves represent the fitted model per treatment. For boxplots, the bottom and top of the box are the first and the third quartiles of the data distribution, the horizontal segment and the dot inside the box are the median and the mean, respectively, 


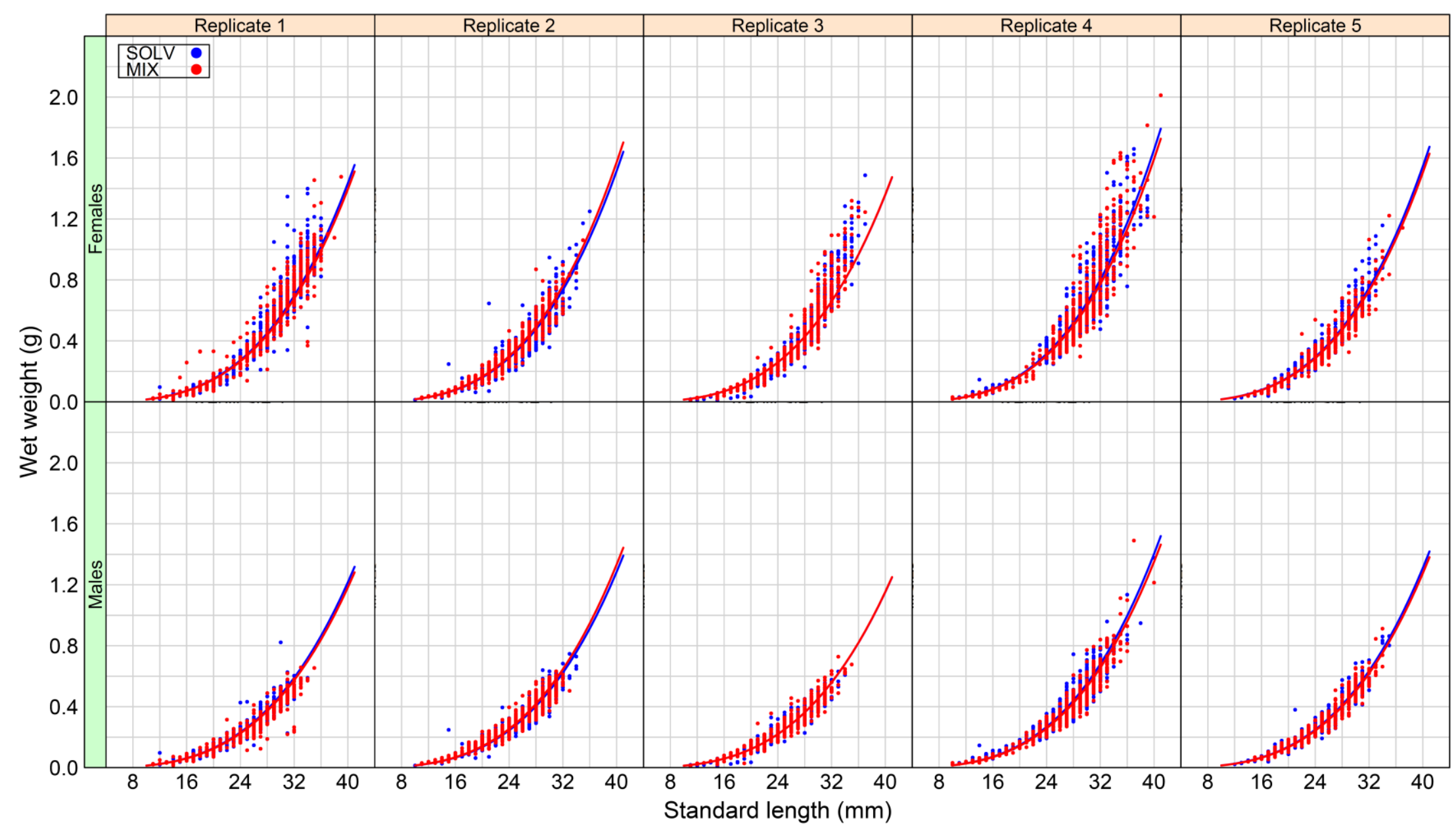

492 Fig. 4. Effect of dietary exposure to a PCB and PBDE congeners mixture on zebrafish body condition. Rows correspond to the sex of fish and columns to the replicates. Dots 493 represent observations per treatment (MIX in red and SOLV in blue) and curves represent the fitted model per treatment. 


\subsection{Spawning probability}

496 Spawning probability increased significantly with age and average length of male and

497 decreased with average length of female $\left(a, \bar{l}_{m}, \bar{l}_{f}\right.$, effects, Table 1; Fig. 5). As mean 498 individual food consumption $c$ had no effect on spawning probability, this covariate was not 499 kept in the reduced model. The overall spawning probability was not affected by exposure to 500 contaminant (no significant $T$ effect, Table 1) but there was a significant interaction effect 501 between treatment and age ( $T \times a$ effect, Table 1) showing that spawning probability in MIX 502 fish increased with age at a slower rate than in SOLV fish (Fig 5). Consequently, over the 503 duration of the reproduction test, SOLV fish had a significantly higher likelihood to spawn 504 compared to MIX fish.

\section{$505 \quad 3.6 \quad$ Number of eggs}

506 The comparison of the cumulative number of eggs produced by all successful spawning 507 events throughout the reproduction test indicated a similar number of eggs produced by MIX 508 fish $(110 \pm 82$ eggs per female) than by SOLV fish $(122 \pm 82$ eggs per female) ( $T$ effect 509 Table 1; Fig. 5). In contrast, the number of eggs produced increased significantly with age and 510 decreased significantly with the number of individuals in tanks ( $a$ and $N$ effects, Table 1). 511 Although the number of eggs produced by MIX fish seemed to increase with age faster than 512 for SOLV fish (Fig. 5), the interaction between treatment and age was not significant $(T \times a$ 513 effect that was not kept in the model).

\section{$514 \quad 3.7 \quad$ Fertilization rate}

515 Fertilization rate increased significantly with age ( $a$ effect, Table 1; Fig. 5) but there was no 516 significant difference between MIX and SOLV fish in terms of both the overall level of 
517 fertilization rate and its increase with age ( $T$ and $T \times a$ effects, Table 1; the latter was not 518 kept in the model; Fig. 5).

519

520

521

522 


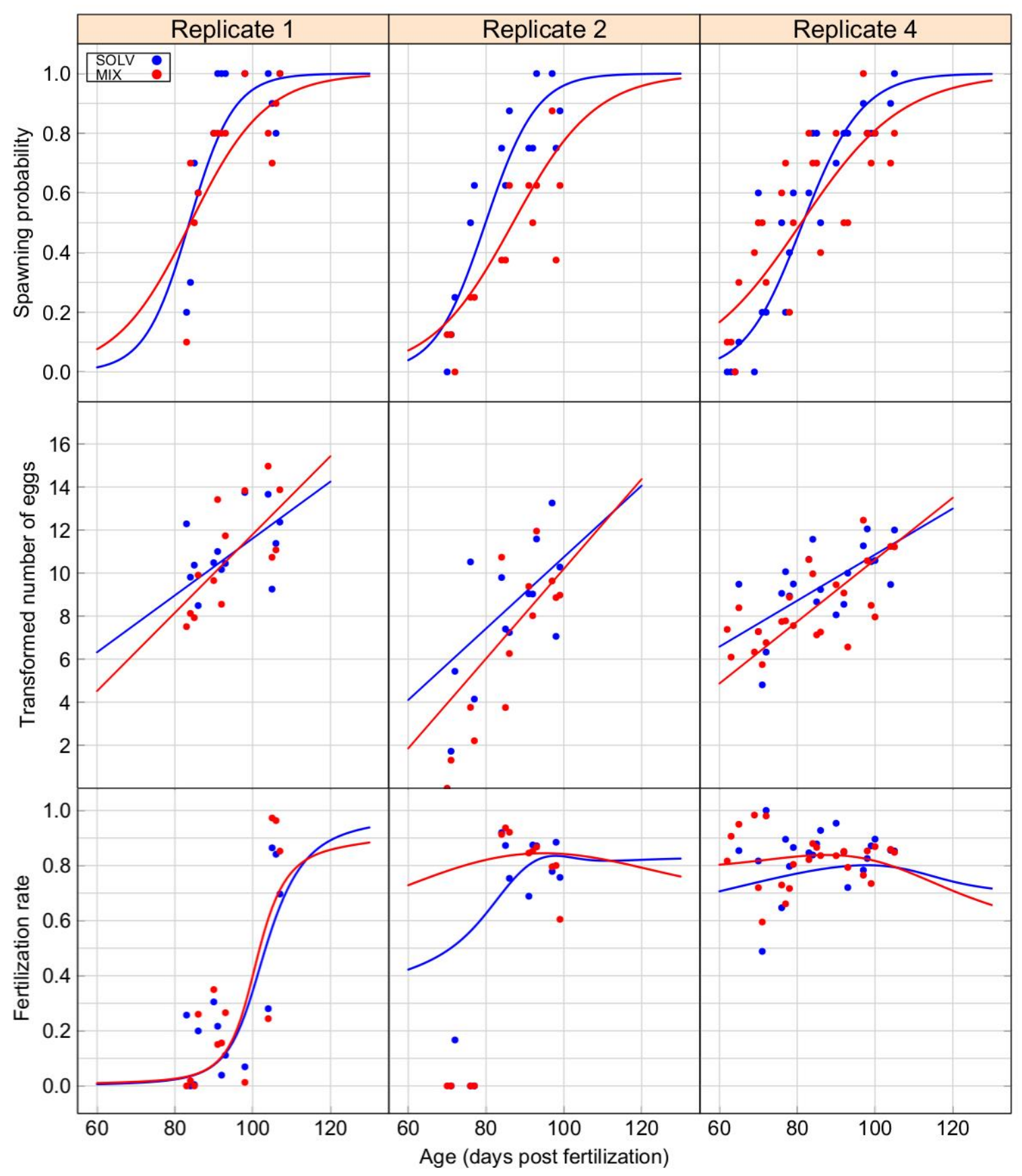

524 Fig. 5. Effect of dietary exposure to a PCB and PBDE congeners mixture on reproduction traits in zebrafish. Rows correspond to the spawning probability, number of eggs (Box-Cox transformed) and fertilization rate, respectively. Traits are represented as functions of age (dpf) in the three replicates (in columns) used for the reproduction test. Dots are for observed reproduction traits in rearing tanks for MIX (in red) and SOLV (in blue) fish and curves represent the fitted model per treatment. 


\subsection{Larval survival in the progeny}

533 The overall level of survival of unfed larvae was unaffected by exposure to contaminants ( $T$

534 effect, Table 2; Fig. 6), but survival differed significantly according to the spawning event 535 considered ( $O$ effect, Table 2) and this difference was dependent on treatment $(T \times O$

536 interaction effect, Table 2). More precisely, survival probability was higher at the $10^{\text {th }} \mathrm{F} 0$ 537 spawning event than at the $1^{\text {st }} \mathrm{F} 0$ spawning event and this difference was more pronounced 538 for larvae originating from MIX progenitors than from SOLV ones (Table 2). This analysis 539 was followed by a post-hoc multiple comparison test (Hothorn et al., 2008) to assess which 540 groups differed from the rest. The test revealed that, on the $1^{\text {st }}$ F0 spawning event, the survival 541 probability of larvae produced by SOLV F0 fish was higher than that of larvae produced by 542 MIX F0 fish (post-hoc test MIX/1 ${ }^{\text {st }}$ spawn vs. SOLV $/ 1^{\text {st }}$ spawn: $Z=-2.55$, p-value $=0.021$, 543 Fig. $6,1^{\text {st }}$ spawning event) whereas no difference was detected on the $10^{\text {th }}$ spawning event 544 (post-hoc test MIX/10 ${ }^{\text {th }}$ spawn vs. SOLV/10 $0^{\text {th }}$ spawn: $Z=0.08$, p-value $=1$, Fig. $6,10^{\text {th }}$ 545 spawning event).

Table 2. Analysis of the effects of dietary treatment (MIX vs. SOLV) on zebrafish F1 larval survival in nonfeeding conditions by a mixed-effects Cox proportional hazards model. For categorical variables, effects are estimated for one category (indicated between parentheses) relative to the reference one taken as the intercept, namely MIX relative to SOLV for treatment $T$, and second observation date $\left(10^{\text {th }}\right.$ spawning event) relative to the first one (1st spawning event) for spawning event $O$.

\begin{tabular}{lllllll}
\hline Trait & Effect & Estimate & s.e. & $\boldsymbol{d f}$ & $\chi^{2}$ & $\boldsymbol{p}$-value \\
\hline \multirow{3}{*}{$\begin{array}{l}\text { Larval survival in } \\
\text { progeny }\end{array}$} & baseline hazard (SOLV/1st spawn) & n.a. & n.a. & n.a. & n.a. & n.a. \\
& $\boldsymbol{O}\left(10^{\text {th }}\right.$ spawn) & -0.405 & 0.283 & 1 & 30.73 & $<\mathbf{0 . 0 0 1}$ \\
& $T(\mathrm{MIX})$ & 0.986 & 0.318 & 1 & 1.65 & 0.198 \\
& $T \times O$ & -1.053 & 0.440 & 1 & 8.92 & $\mathbf{0 . 0 0 3}$ \\
\hline
\end{tabular}

p-values $<0.05$ are in bold. 

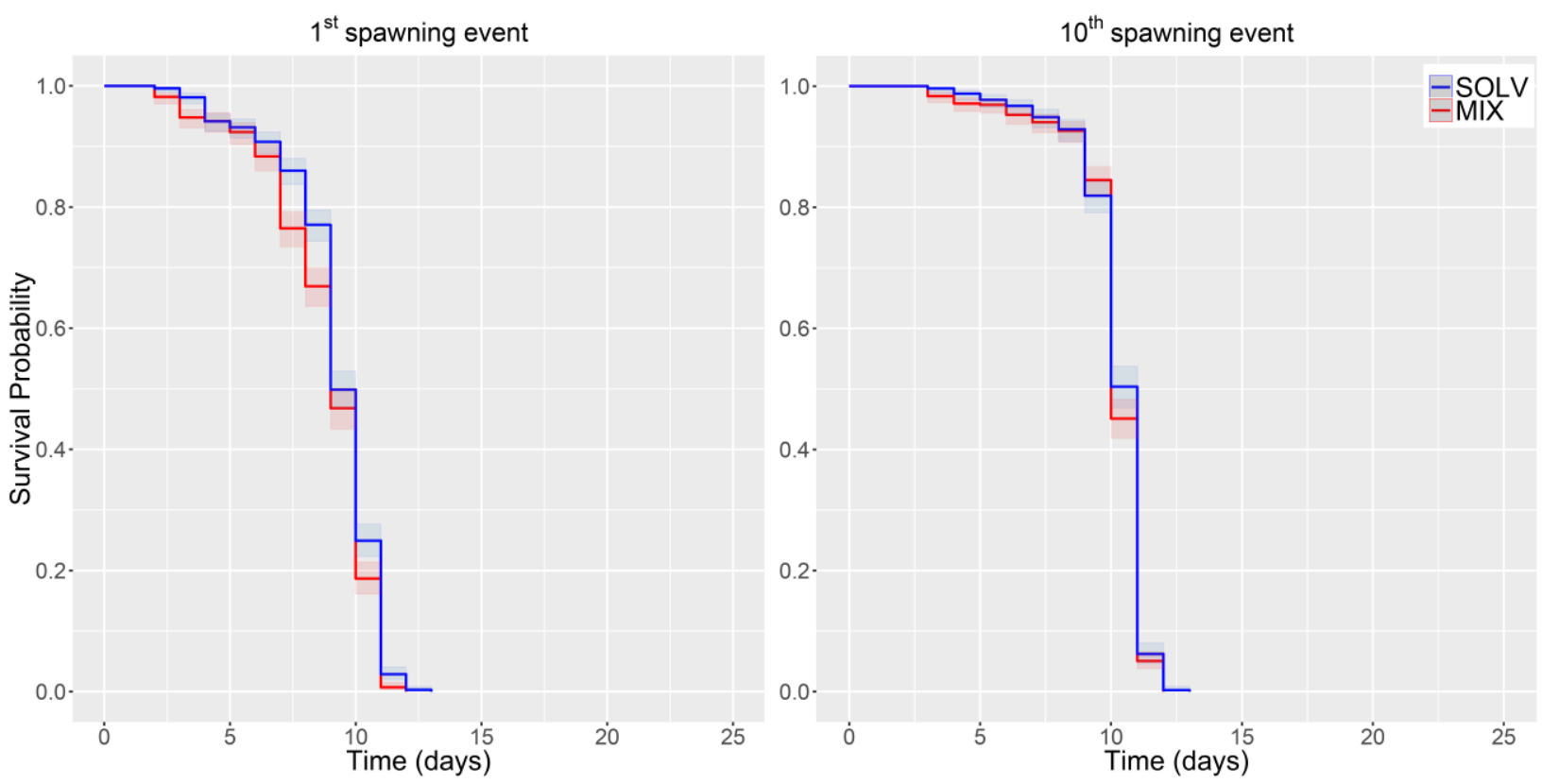

Fig. 6. Effect of parental (F0) dietary exposure to a PCB and PBDE congeners mixture on the survival of unfed offspring (F1) larvae in zebrafish. Curves represent the estimated decrease in individuals' survival probability with time by Kaplan-Meier estimator for MIX (red) and SOLV (blue) treatment, respectively, and shaded areas are the corresponding confidence intervals. 


\section{Discussion}

570

571

572

573

574

575

576

577

578

579

580

581

582

583

584

\subsection{PCB and PBDE levels in MIX and SOLV fish}

The very low concentration of PCB and PBDE congeners measured in SOLV diet showed that no external or cross-contamination between treatments occurred during diet preparation and exposure experiment. In contrast, MIX diet was actually contaminated with spiking efficiencies ranging from 86 to $130 \%$ of targeted concentrations (Table S1). As a result, concentrations of PCB and PBDE congeners measured in both females and males were clearly higher in MIX fish than in SOLV ones (80-85 times and 35-100 times, respectively). PBDE levels in fish at the end of the experiment were in the range of those reported in fish from European industrialized estuaries (Law et al., 2006). PCB levels at the end of the experiment were also in the range of those encountered in the environment (Robinson et al., 2017). These results show the ability of these contaminants to accumulate in fish tissues through trophic contamination and allow us to assign the observed differences between MIX and SOLV fish life-history traits to the effects of the trophic transfer of the PCB/PBDE mixture.

\subsection{Effects on survival of exposed fish}

No difference in early and juvenile/adult survival was observed between SOLV and MIX fish. Our result on early survival is in accordance with a study describing the effects of exposure to a single congener of PBDE (BDE-47) in zebrafish on roughly the same part of the life-cycle (Chou et al., 2010). PCBs and PBDEs have been shown to accumulate over time in fish tissues in experimental conditions (Daouk et al., 2011; Nyholm et al., 2009). However, as food was spiked at environmental doses, the contamination levels in tissues was relatively low during the entire life cycle, which may explain the absence of acute mortality in MIX fish at any stage. The second point that might explain the absence of a difference in survival between 
MIX and SOLV fish, specifically at early stage, is that the exposure began at the larval stage

593 from mouth opening (at $5 \mathrm{dpf}$ ) and not at the embryonic stage, which has been described as 594 the most critical life-stage (Belanger et al., 2010). Indeed, previous studies in sole showed that exposure to POPs (among which PCBs and PBDEs) at the embryonic stage, i.e. eggs, via the water can lead to a delayed effect on survival during larval stage from mouth opening until

597 metamorphosis (Foekema et al., 2012). Furthermore, Lema et al. (2007) also observed a 598 decrease in zebrafish larval survival after exposure to high concentrations of BDE-47 from embryonic to larval stages. These studies therefore suggest that exposure to POPs at early embryonic stages, as for example through maternal transfer of accumulated pollutants into

601 eggs, may affect larval survival. In the present study, such potential effects were not tested 602 through the analysis of exposed fish early survival, but through the analysis of the larval 603 survival of their progeny (see subsection "Larval survival of exposed fish progeny" below).

\subsection{Effects on growth of exposed fish}

In both sexes, MIX fish grew to larger lengths (asymptotic length $l_{\infty}$ ) than SOLV fish but at a

606 slower pace (growth rate coefficient $k$ ). This result contrasts with other studies in which long 607 term exposure to POP mixtures were performed. Dietary exposure of zebrafish to mixtures of 608 polycyclic aromatic hydrocarbons (PAHs) produced a decrease in both weight and length 609 (Vignet et al., 2014), the amplitude of which depended on PAHs concentrations and fish's 610 sex. Such reduction in length growth as well as reduction in body condition was also observed 611 after a short exposure via the water of sole juveniles to a PAH mixture at high concentration 612 mimicking an oil spill (Gilliers et al., 2012). In another experiment, the dietary exposure of 613 zebrafish to environmentally realistic freshwater mixtures of POPs (including PCBs and 614 PBDEs as part of the major contaminants identified) produced a significant increase in weight 615 without changes in fish length, i.e. a significant increase in fish condition (Nourizadeh- 
616 Lillabadi et al., 2009). Analyses of gene expression indicated disruption of endogenous

617 hormone function, including genes involved in growth regulation (Berg et al., 2011; Lyche et

618 al., 2011, 2010; Nourizadeh-Lillabadi et al., 2009). Taken together, these reports suggest that

619 POP mixtures can increase or decrease growth in length and/or in weight depending on their

620 chemical composition, which is indicative of the triggering of different mechanisms.

621 However, in the above mentioned studies, the ratio of weight to length is either unchanged as

622 in the present study (Vignet et al., 2014), increased (Nourizadeh-Lillabadi et al., 2009) or 623 decreased (Gilliers et al., 2012). Regarding fish condition, our results showed no effect of an 624 environmentally realistic marine mixture of PCBs and PBDEs on fish condition or length625 weight relationship, suggesting that weight was affected by exposure only according to its 626 allometric relationship with length. In zebrafish, early growth rate is very important in 627 juveniles and slows down at the time of sexual maturation (Gómez-Requeni et al., 2010). The 628 higher growth rate in MIX fish may therefore be related to changes in the sexual maturation 629 process, which may be delayed in MIX fish.

\subsection{Effects on reproduction of exposed fish}

631 Three different aspects of reproduction were evaluated, namely the spawning probability, the 632 number of eggs and the fertilization rate. Spawning probability increased with age faster in 633 SOLV fish than in MIX fish, thus revealing a delay in reproduction in the latter. This result is 634 contradictory with the earlier onset of puberty observed after exposure of zebrafish to a 635 freshwater POP mixture (Nourizadeh-Lillabadi et al., 2009). However, in this earlier study 636 and as previously stated, exposure produced an increase in female condition, which is one 637 important positive driver of maturation and thus spawning probability in fish (Grift et al., 638 2007; Mollet et al., 2007; Uusi-Heikkilä et al., 2011; Wright, 2007). Numerous studies have 639 demonstrated that POPs may act as endocrine disrupters by disrupting hormone pathways that regulate reproductive functions, leading to a decrease in reproductive success components 
641 such as egg production and fertilization rate in fish (reviewed in Mills and Chichester, 2005;

642 Yu et al., 2015). For instance, Muirhead et al. (2006) showed that exposure to BDE-47 caused

643 a significant reduction in mature sperm in fathead minnows, suggesting that PBDEs can affect

644 male reproductive function and reduce male fertility. In the present study, the delayed

645 increase in reproductive output observed in MIX fish could also be explained by such

646 disruption caused by PCBs and PBDEs producing a delay in follicle maturation as this has

647 been shown after exposure to PCBs (Daouk et al., 2011) or PAHs (Vignet et al., 2016).

648 In the present study, MIX fish produced on average similar eggs per female than SOLV fish.

649 Previous works have shown that PCBs and PBDEs reduce clutch size in zebrafish (Kuiper et

650 al., 2008; Muirhead et al., 2006; Örn et al., 1998). Note however that contaminants were

651 administered at very high doses in these studies unlike in the present study during which the

652 mixture of PCBs and PBDEs was administered at doses representative of the marine

653 environment. Hence, PCBs and PBDEs might have not reached a sufficient concentration in

654 fish tissue to alter clutch size in the present study. For example, Kuiper et al. (2008) observed

655 no effect of BDE-71 (commercial pentabromodiphenylether mixture) on zebrafish egg

656 production at environmentally relevant exposure, but they suspected a decrease in egg

657 production when fish were exposed to higher levels of BDE-71. However, this decrease in

658 egg production was not statistically significant, likewise in the present study. In addition to

659 the number of eggs, several other reproduction traits can be used in order to give more

660 information on realized fecundity or reproductive output. Indeed, realized fecundity can be

661 seen as the combination of spawning probability and clutch size. In the present study, the

662 combination of delayed spawning probability and an unaltered increase in clutch size with age

663 can thus be interpreted as a diminution of realized fecundity at young ages for MIX treatment.

664 Besides fecundity, fertilization rate did not differ between MIX and SOLV fish. This contrasts

665 with previous studies in zebrafish where exposure to environmentally relevant concentrations 
666 of PCB congeners via diet (Daouk et al., 2011) or of BDE-71 via water (Han et al., 2013)

667 could reduce fertilization success. However, the effect of a mixture of PCBs and PBDEs may 668 differ from those assessed for a single type of POPs (Daouk et al., 2011) or a single congener 669 (Han et al., 2013) because of potentially differing mechanisms of action between PCBs and 670 PBDEs as well as synergistic and antagonistic effects. In addition, fertilization can be highly 671 variable within one treatment, which makes mean fertilization rate a poor predictor (Vignet et 672 al., 2016).

673 Beyond exposure to PCBs and PBDEs, spawning probability and the number of eggs 674 produced could also depend on other factors. Previous studies have shown that the probability 675 of spawning in zebrafish increases with length of female (Paull et al., 2008; Spence and 676 Smith, 2006; Uusi-Heikkilä et al., 2010) and male (Pyron, 2003). The latter is in agreement 677 with our results that showed an increase in spawning probability with average male length 678 that could be explained by female mating preferences for larger males (Pyron, 2003). In 679 contrast, the observed decrease in spawning probability with average female length has never 680 been reported before and seems rather counter-intuitive. However, another aspect that should 681 be taken into account is the fact that fish used for reproduction tests were young adults. In 682 zebrafish, female reach sexual maturity earlier than males (Gonzales, 2012), which is 683 associated to larger weight and condition (Cousin et al., 2012; Gómez-Requeni et al., 2010). 684 Therefore mature females are larger than males of the same age, which was confirmed by our 685 results on growth and condition. In turn, if the preference of females for larger males implies 686 that males should be larger than females themselves, then such choosiness could favor 687 reproduction of the smaller females as they could find larger males more easily, especially in 688 experimental populations where all individuals have the same age. 
690 Maternal transfer of contaminants in general - i.e., heavy metals, organochlorine pesticides,

691 PAHs, PCBs - to offspring has been well documented in many species, including birds 692 (Ackerman et al., 2016; Bargar et al., 2001), amphibians (Metts et al., 2013), and reptiles 693 (Rauschenberger et al., 2007). In fish, several studies have focused more specifically on the 694 maternal transfer of POPs to eggs, particularly PCBs and PBDEs, because of their high 695 concentrations and widespread occurrence in aquatic environments (e.g. Daouk et al., 2011; 696 Miller, 1993; Niimi, 1983; Nyholm et al., 2008; Yu et al., 2011; Zhang et al., 2010). These 697 compounds have lipophilic properties that provide a route for transfer from a female's stored lipids to offspring through eggs. In other words, PCBs and PBDEs present in a female's body 699 fat are transported to its oocytes via egg yolk lipoproteins derived from vitellogenin (Nyholm 700 et al., 2008; Russell et al., 1999; Ungerer and Thomas, 1996; Zhang et al., 2010). Given such 701 maternal transfer and the documented detrimental effect on larval performances of exposure 702 to POPs at embryonic stage (Foekema et al., 2012, 2014; Grimes et al., 2008; Yu et al., 2011), 703 the elevated mortality observed in unfed larvae descending from exposed fish in the present 704 study was expected.

However, survival probability in unfed larvae descending from MIX fish increased from the $1^{\text {st }}$ to the $10^{\text {th }}$ spawning event so as to become similar to that of larvae originating from SOLV fish. This increase may be related to a gain in egg quality as females age and thus between early and later spawns, which is a common phenomenon in teleost fish (Brooks et al., 1997; Brunel, 2010; Nasiadka and Clark, 2012; Trippel et al., 1997). More precisely, one may hypothesizes that there was a gain in egg quality between the $1^{\text {st }}$ and the $10^{\text {th }}$ spawning event

711 that compensated for the detrimental effect of PCBs and PBDEs transferred from mothers to 712 their eggs. These results suggest that the negative effect of a realistic marine mixture of PCBs and PBDEs on larval survival may be mostly expressed in young females' progeny. 


\subsection{Energy-allocation interpretation and life-history implications}

715 In terms of bioenergetics, life-history traits are considered as resulting from the allocation of

716 limited energy resources acquired through feeding to three main compartments: maintenance,

717 growth and reproduction (Partridge et al., 1991; Perrin and Sibly, 1993; Stearns, 1992). These

718 compartments are supposed to be linked by energy-based trade-offs, so that any increase in

719 resource allocation to one trait should be correlated with a decrease in allocation to the others.

720 This is for example suggested by the slowing-down of growth at the beginning of sexual 721 maturation (Gómez-Requeni et al., 2010). In our study, the increase in individual growth and

722 the decrease in the reproductive output observed in exposed fish can be interpreted in terms of

723 the energetic trade-off between growth and reproduction. In other words, it suggests that the

724 mixture of PCBs and PBDEs altered the allocation of energy between these two

725 compartments, with fish diverting more energy towards somatic growth at the expense of the

726 reproductive function, and hence, MIX fish grew larger than SOLV fish but reproduced later.

727 These results are consistent with the fact that PCBs and PBDEs are known endocrine

728 disruptors favoring obesity (Berg et al., 2011; Lyche et al., 2011, 2010; Nourizadeh-Lillabadi

729 et al., 2009) and impairing reproduction (Mills and Chichester, 2005; Yu et al., 2015), which

730 can be seen as favoring energy investment towards soma against of gonads. These direct

731 bioenergetic effects linked to the suspected endocrine activity of the PCB/PBDE mixture are

732 additional to and independent from the indirect bioenergetics effect on basal metabolism and

733 energy dedicated to maintenance due to detoxification that is often observed in contaminated

734 individuals (Jørgensen et al., 2016; Kumaraguru and Beamish, 1983; Newman and Clements,

735 2008). The latter is supposed to be relatively weak in our case given that the PCB/PBDE

736 mixture was administered at low environmental doses and that lethal effects were only 737 observed at larval stage in the progeny. 
In contrast to their suspected effect on the energetic trade-off between somatic growth and

739 reproduction, a purely obesogenic effect of the PCB and PBDE mixture seems unlikely.

740 Despite the fact that a variety of environmental endocrine disrupting chemicals such as POPs

741 can cause changes in fat mass and subsequent obesity as it has been observed in fish (Berg et

742 al., 2011; Lyche et al., 2010, 2011; Nourizadeh-Lillabadi et al., 2009), humans (Dirinck et al.,

743 2011; Grün and Blumberg, 2009) and rats (Grün and Blumberg, 2009), the present study

744 shows indeed no difference in condition between MIX and SOLV fish. Still, the present

745 results do not allow rejecting the possibility that these compounds could cause simultaneous

746 but independent changes in body growth and the reproductive function.

747 Another question is the net effect of these changes in growth and reproduction on individuals'

748 reproductive output throughout the whole life-cycle, and thus their fitness. Given that

749 fecundity is known to increase with length in teleost fish species (Kamler, 2012), it remains to

750 be investigated whether the potential gain in fecundity due to the increase in body growth

751 could (over-)compensate for delayed reproduction and potentially smaller clutch size at a

752 given age. A study based on bioenergetics modeling may help to answer this question and to

753 confirm the alteration of the energetic trade-off between growth and reproduction.

754 Bioenergetic models at the individual level are often used to describe the effects of chemical

755 stressors and their physiological modes of action (e.g. feeding, maintenance, reproduction,

756 growth) (Álvarez et al., 2006; Augustine et al., 2012; Martin et al., 2013). They are also

757 especially well adapted for extrapolating individual effects of stressors to populations

758 (Beaudouin et al., 2015; Jager and Klok, 2010; Kooijman and Metz, 1984; Martin et al.,

759 2013). One of the best-tested and most extensive bioenergetic approaches is the Dynamic

760 Energy Budget theory (DEB) (Kooijman, 2010; Sousa et al., 2010), which describes the rates

761 at which an individual organism acquires energy and utilizes it for three energetic

762 compartments, namely maintenance, growth and reproduction or maturity. Developing such a 
model to investigate the effects of an environmentally realistic marine mixture of PCBs and

764 PBDEs would allow assessing (i) whether changes in growth and reproduction can be 765 independent or not by testing theoretically different physiological mode of actions and (ii)

766 whether they could compensate each other in terms of consequences on lifetime reproductive 767 output and fitness.

\subsection{Potential consequences of life-history effects of environmental mixtures of PCBs} and PBDEs on fish population dynamics

770

771

772

773

774

Contaminant exposure may have serious implications for population dynamics and, consequently, on the structure of ecosystems as shown in many species (Barnthouse et al., 1990; Klok and de Roos, 1996; Munns et al., 1997). However, the effects of POPs on the population dynamics of fish, especially on exploited marine fish, are still poorly investigated. This study shows that chronic dietary exposure to an environmentally realistic marine mixture of POPs can delay reproduction and decrease progeny larval survival under starvation conditions while increasing body growth in zebrafish. We acknowledge that the results reported here using a freshwater species may not fully apply to marine fish, especially when considering the additional metabolic costs due to osmotic pressure maintenance in an hyperosmotic environment. There are however a large number of articles reporting similar toxicity pathways in marine and freshwater fish species for a number of biological functions such as growth (Bodiguel et al., 2009; Daouk et al., 2011), behavior (Gravato and Guilhermino, 2009; Oliveira et al., 2012; Vignet et al., 2017) and reproduction (Sun et al., 2015; Vignet et al., 2016). These studies therefore support the hypothesis that the present results on a freshwater fish species are indicative of what could happen in marine fish. Under the assumption that these life-history effects can be transposed to marine teleost fish in the wild, they may have detrimental consequences on their population dynamics. 
787 Marine fish population recruitment is known to depend strongly on food availability, 788 especially during the critical period corresponding to the transition from endogenous to 789 exogenous feeding (Hjort, 1914), and on the match or mismatch between larvae emergence 790 timing and that of their prey (Cushing, 1990), which can partly depend on hydrodynamic 791 factors (Cury and Roy, 1989; Lasker, 1978). Starvation episodes during larval stages are 792 common and generally lead to lower recruitment and smaller year classes (Cushing, 1990; 793 Leaf and Friedland, 2014; Lusseau et al., 2014; Pritt et al., 2014). The results of this study on 794 progeny larval survival suggest that exposure to PCBs and PBDEs in the marine environment 795 could amplify the detrimental consequences of starvation on larval survival and the resulting 796 decrease in recruitment level due to maternal transfer. This is in line with the hypothesis that 797 the recruitment of some exploited marine fish species could be impaired due to nursery 798 degradation partly related to the accumulation of PCBs and PBDEs (Gilliers et al., 2006; Riou 799 et al., 2001; Rochette et al., 2010, 2012). Moreover, lower reproductive output because of 800 delayed reproduction may also decrease recruitment although this effect may be partly 801 compensated for by the observed increase in body growth and the associated increase in 802 fecundity due to its dependency on length.

803 Finally, these life-history effects may also render commercial fish populations more 804 vulnerable to exploitation. Increased growth could increase fishing mortality at young ages as 805 fisheries select most often larger individuals (Garcia et al., 2012) while delayed reproduction 806 could diminish spawning stock biomass (Enberg et al., 2010; Fiorentino et al., 2008) and 807 lower larval survival could decrease its reproductive output. Moreover, the typical diminution 808 in the average age of the spawning stock due to fishing (Berkeley et al., 2004; Brunel, 2010; 809 Ottersen et al., 2006) could favor the expression of the decrease in larval survival due to the 810 exposure to PCBs and PBDEs documented in the present study, and thus amplify the potential 811 negative effect on total reproductive output. As a result, population growth rates of exploited 
812 fish could diminish under exposure to POPs so that they may sustain lower exploitation levels

813 and produce lower fishing yields.

814

815

816

817

818

819

820

821

822

823

824

825

826

827

828

829 
831 We thank Lucette Joassard, Didier Leguay and Cathy Haget from Ifremer LRH for their 832 valuable help in daily rearing duties and Paul Bodin from Ifremer LRH for gathering data 833 during the first year of this experiment. This research was funded by the French National 834 Research Agency, project Fish'N'POPs (ANR-13-CESA-020). K. Horri received a PhD grant 835 from Ifremer and Région Haute Normandie and S. Alfonso received a Master and PhD grant 836 from Ifremer to conduct this research. Nathalie Olivier and Xavier Philippon from Ifremer 837 (LBCO) are acknowledged for their participation in PCB and PBDE analyses. 
Abarnou, A., Burgeot, T., Chevreuil, M., Leboulenger, F., Loizeau, V., Madoulet-Jaouen, A.,Minier, C., 2000. Les contaminants organiques. Quels risques pour le monde vivant?, Editions IFREMER.

842

843

844

845

846

847

848

849

850

851

852

853

854

855

856

857

858

859

860

861

862

863

864

865

866

867

868

869

870

871

872

873

874

875

876

Ackerman, J.T., Eagles-Smith, C.A., Herzog, M.P., Hartman, C.A., 2016. Maternal transfer of contaminants in birds: mercury and selenium concentrations in parents and their eggs. Environ. Pollut. 210, 145-154.

Álvarez, O.A., Jager, T., Redondo, E.M., Kammenga, J.E., 2006. Physiological modes of action of toxic chemicals in the nematode Acrobeloides nanus. Environ. Toxicol. Chem. 25, $3230-3237$.

Augustine, S., Gagnaire, B., Adam-Guillermin, C., Kooijman, S.A.L.M., 2012. Effects of uranium on the metabolism of zebrafish, Danio rerio. Aquat. Toxicol. 118-119, 926.

Baillon, L., Pierron, F., Pannetier, P., Normandeau, E., Couture, P., Labadie, P., Budzinski, H., Lambert, P., Bernatchez, L., Baudrimont, M., 2016. Gene transcription profiling in wild and laboratory-exposed eels: effect of captivity and in situ chronic exposure to pollution. Sci. Total Environ. 571, 92-102.

Bargar, T.A., Scott, G.I., Cobb, G.P., 2001. Maternal transfer of contaminants: case study of the excretion of three polychlorinated biphenyl congeners and technical-grade endosulfan into eggs by white leghorn chickens (Gallus domesticus). Environ. Toxicol. Chem. 20, 61-67.

Barnthouse, L.W., Suter, G.W., Rosen, A.E., 1990. Risks of toxic contaminants to exploited fish populations: influence of life history, data uncertainty and exploitation intensity. Environ. Toxicol. Chem. 9, 297-311.

Bates, D., Mächler, M., Bolker, B., Walker, S., 2015. Fitting linear mixed-effects models using lme4. J. Stat. Softw. 1 (1) (2015).

Beaudouin, R., Goussen, B., Piccini, B., Augustine, S., Devillers, J., Brion, F., Péry, A.R.R., 2015. An individual-based model of zebrafish population dynamics accounting for energy dynamics. PLoS One 10, e0125841.

Belanger, S.E., Balon, E.K., Rawlings, J.M., 2010. Saltatory ontogeny of fishes and sensitive early life stages for ecotoxicology tests. Aquat. Toxicol. 97, 88-95.

Berg, V., Lyche, J.L., Karlsson, C., Stavik, B., Nourizadeh-Lillabadi, R., Hårdnes, N., Skaare, J.U., Alestrøm, P., Lie, E., Ropstad, E., 2011. Accumulation and effects of natural mixtures of persistent organic pollutants (POP) in zebrafish after two generations of exposure. J. Toxic. Environ. Health A 74, 407-423.

Berkeley, S.A., Hixon, M.A., Larson, R.J., Love, M.S., 2004. Fisheries sustainability via protection of age structure and spatial distribution of fish populations. Fisheries 29, 23-32.

Bodiguel, X., Loizeau, V., Le Guellec, A.-M., Roupsard, F., Philippon, X., Mellon-Duval, C., 2009. Influence of sex, maturity and reproduction on PCB and p,p âTM DDE concentrations and repartitions in the European hake (Merluccius merluccius, L.) from the Gulf of Lions (NW Mediterranean). Sci. Total Environ. 408, 304-311. 
Bogdal, C., Scheringer, M., Abad, E., Abalos, M., van Bavel, B., Hagberg, J., Fiedler, H., 2013. Worldwide distribution of persistent organic pollutants in air, including results of air monitoring by passive air sampling in five continents. TrAC Trends Anal. Chem. 46, 150161.

Brooks, S., Tyler, C.R., Sumpter, J.P., 1997. Egg quality in fish: what makes a good egg? Rev. Fish Biol. Fish. 7, 387-416.

Brunel, T., 2010. Age-structure-dependent recruitment: a meta-analysis applied to Northeast Atlantic fish stocks. ICES J. Mar. Sci. 67, 1921-1930.

Burd, B.J., Macdonald, T.A., Macdonald, R.W., Ross, P.S., 2014. Distribution and uptake of key polychlorinated biphenyl and polybrominated diphenyl ether congeners in benthic infauna relative to sediment organic enrichment. Arch. Environ. Contam. Toxicol. 67, 310-334.

Byer, J.D., Lebeuf, M., Trottier, S., Raach, M., Alaee, M., Stephen Brown, R., Backus, S., Casselman, J.M., Hodson, P.V., 2015. Trends of persistent organic pollutants in American eel (Anguilla rostrata) from eastern Lake Ontario, Canada, and their potential effects on recruitment. Sci. Total Environ. 529, 231-242.

Chou, C.-T., Hsiao, Y.-C., Ko, F.-C., Cheng, J.-O., Cheng, Y.-M., Chen, T.-H., 2010. Chronic exposure of 2,2',4,4'-tetrabromodiphenyl ether (PBDE-47) alters locomotion behavior in juvenile zebrafish (Danio rerio). Aquat. Toxicol. 98, 388-395.

Christensen, J.H., Glasius,M., Pécseli, M., Platz, J., Pritzl, G., 2002. Polybrominated diphenyl ethers (PBDEs) in marine fish and blue mussels from southern Greenland. Chemosphere 47, 631-638.

Corsolini, S., 2009. Industrial contaminants in Antarctic biota. J. Chromatogr. A 1216, 598612.

Couderc, M., Poirier, L., Zalouk-Vergnoux, A., Kamari, A., Blanchet-Letrouvé, I., Marchand, P., Vénisseau, A., Veyrand, B., Mouneyrac, C., Le Bizec, B., 2015. Occurrence of POPs and other persistent organic contaminants in the European eel (Anguilla anguilla) from the Loire estuary, France. Sci. Total Environ. 505, 199-215.

Cousin, X., Daouk, T., Péan, S., Lyphout, L., Schwartz, M.-E., Bégout, M.-L., 2012. Electronic individual identification of zebrafish using radio frequency identification (RFID) microtags. J. Exp. Biol. 215, 2729-2734.

Cury, P., Roy, C., 1989. Optimal environmental window and pelagic fish recruitment success in upwelling areas. Can. J. Fish. Aquat. Sci. 46, 670-680.

Cushing, D.H., 1990. Plankton production and year-class strength in fish populations: an update of the match/mismatch hypothesis. In: Southward, J.H.S.B., A.J. (Eds.), Advances in Marine Biology. Academic Press, pp. 249-293.

Daouk, T., Larcher, T., Roupsard, F., Lyphout, L., Rigaud, C., Ledevin, M., Loizeau, V., Cousin, X., 2011. Long-term food-exposure of zebrafish to PCBmixturesmimicking some environmental situations induces ovary pathology and impairs reproduction ability. Aquat. Toxicol. 105, 270-278. 
De Roos, A.M., Persson, L.,McCauley, E., 2003. The influence of size-dependent life-history traits on the structure and dynamics of populations and communities. Ecol. Lett. 6, 473-487.

918 Desforges, J.-P.W., Dangerfield, N., Shaw, P.D., Ross, P.S., 2014. Heightened biological uptake of polybrominated diphenyl ethers relative to polychlorinated biphenyls nearsource revealed by sediment and plankton profiles along a coastal transect in British Columbia. Environ. Sci. Technol. 48, 6981-6988.

Development Core Team, R., 2015. R: A Language and Environment for Statistical Computing. R Foundation for Statistical Computing, Vienna, Austria.

Dinn, P.M., Johannessen, S.C., Ross, P.S., Macdonald, R.W., Whiticar, M.J., Lowe, C.J., van Roodselaar, A., 2012. PBDE and PCB accumulation in benthos near marine waste water outfalls: the role of sediment organic carbon. Environ. Pollut. 171, 241-248.

Dirinck, E., Jorens, P.G., Covaci, A., Geens, T., Roosens, L., Neels, H., Mertens, I., van Gaal, L., 2011. Obesity and persistent organic pollutants: possible obesogenic effect of organochlorine pesticides and polychlorinated biphenyls. Obesity 19, 709-714.

Enberg, K., Jørgensen, C., Mangel, M., 2010. Fishing-induced evolution and changing reproductive ecology of fish: the evolution of steepness. Can. J. Fish. Aquat. Sci. 67, 17081719.

Fiorentino, F., Badalamenti, F., D'Anna, G., Garofalo, G., Gianguzza, P., Gristina,M., Pipitone, C., Rizzo, P., Fortibuoni, T., 2008. Changes in spawning-stock structure and recruitment pattern of red mullet, Mullus barbatus, after a trawl ban in the Gulf of Castellammare (central Mediterranean Sea). ICES J. Mar. Sci. 65, 1175-1183.

Foekema, E.m., Fischer, A., Parron, M.L., Kwadijk, C., de Vries, P., Murk, A.j., 2012. Toxic concentrations in fish early life stages peak at a critical moment. Environ. Toxicol. Chem. 31, $1381-1390$.

940 Foekema, E.M., Lopez Parron, M., Mergia, M.T., Carolus, E.R.M., vd Berg, J.H.J., Kwadijk, 941 C., Dao, Q., Murk, A.J., 2014. Internal effect concentrations of organic substances for early 942 life development of egg-exposed fish. Ecotoxicol. Environ. Saf. 101, 14-22.

943 Fox, J.,Weisberg, S., 2011. An R Companion to Applied Regression. 2nd ed. SAGE 944 Publications, Los Angeles, CA (ed).

945 Froese, R., 2006. Cube law, condition factor and weight-length relationships: history, meta946 analysis and recommendations. J. Appl. Ichthyol. 22, 241-253.

947 Garcia, S.M., Kolding, J., Rice, J., Rochet, M.-J., Zhou, S., Arimoto, T., Beyer, J.E., Borges, 948 L., Bundy, A., Dunn, D., Fulton, E.A., Hall, M., Heino, M., Law, R., Makino, M., Rijnsdorp, 949 A.D., Simard, F., Smith, A.D.M., 2012. Reconsidering the consequences of selective 950 fisheries. Science 335, 1045-1047.

951 Gilliers, C., Le Pape, O., Desaunay, Y., Morin, J., Guerault, D., Amara, R., 2006. Are growth 952 and density quantitative indicators of essential fish habitat quality? An application to the 953 common sole Solea solea nursery grounds. Estuar. Coast. Shelf Sci. 69, 96-106. 
Gilliers, C., Claireaux, G., Galois, R., Loizeau, V., Le Pape, O., 2012. Influence of hydrocarbons exposure on survival, growth and condition of juvenile flatfish. J. Life Sci 4, $113-122$.

Gómez-Requeni, P., Conceição, L.E.C., Jordal, A.-E.O., Rønnestad, I., 2010. A reference growth curve for nutritional experiments in zebrafish (Danio rerio) and changes in whole body proteome during development. Fish Physiol. Biochem. 36, 1199-1215.

Gonzales, J.M., 2012. Preliminary evaluation on the effects of feeds on the growth and early reproductive performance of zebrafish (Danio rerio). J. Am. Assoc. Lab. Anim. Sci. 51, 412417.

Gravato, C., Guilhermino, L., 2009. Effects of benzo(a)pyrene on seabass (Dicentrarchus labrax L.): biomarkers, growth and behavior. Hum. Ecol. Risk Assess. Int. J. 15, 121-137.

Grift, R.E., Heino, M., Rijnsdorp, A.D., Kraak, S.B.M., Dieckmann, U., 2007. Three dimensional maturation reaction norms for North Sea plaice. Mar. Ecol. Prog. Ser. 334, $213-$ 224.

Grimes, A.C., Erwin, K.N., Stadt, H.A., Hunter, G.L., Gefroh, H.A., Tsai, H.-J., Kirby,M.L., 2008. PCB126 exposure disrupts zebrafish ventricular and branchial but not early neural crest development. Toxicol. Sci. 106, 193-205.

Grimm, F., Hu, D., Kania-Korwel, I., Lehmler, H., Ludewig, G., Hornbuckle, K., Duffel, M., Bergman, A., Robertson, L., 2015. Metabolism and metabolites of polychlorinated biphenyls (PCBs). Crit. Rev. Toxicol. 45, 245-272.

Grün, F., Blumberg, B., 2009. Endocrine disrupters as obesogens. Mol. Cell. Endocrinol. 304, 19-29.

Hamilton, P.B., Cowx, I.G., Oleksiak, M.F., Griffiths, A.M., Grahn, M., Stevens, J.R., Carvalho, G.R., Nicol, E., Tyler, C.R., 2015. Population-level consequences for wild fish exposed to sublethal concentrations of chemicals - a critical review. Fish Fish. 17, 545-566.

Han, X.B., Lei, E.N.Y., Lam, M.H.W.,Wu, R.S.S., 2011. AWhole Life Cycle Assessment on Effects of Waterborne PBDEs on Gene Expression Profile along the Brain-Pituitary-Gonad Axis and in the Liver of Zebrafish. Marine Pollution Bulletin, 6th International Conference on Marine Pollution and Ecotoxicology. Vol. 63, pp. 160-165.

Han, X.B., Yuen, K.W.Y.,Wu, R.S.S., 2013. Polybrominated diphenyl ethers affect the reproduction and development, and alter the sex ratio of zebrafish (Danio rerio). Environ. Pollut. 182, 120-126.

Hawker, D.W., Connell, D.W., 1988. Octanol-water partition coefficients of polychlorinated biphenyl congeners. Environ. Sci. Technol. (USA) 22, 382-387.

Hjort, J., 1914. Fluctuations in the Great Fisheries of Northern Europe. (Viewed in the light of biological research). Conseil Permanent International Pour L'Exploration de la Mer.

Hothorn, T., Bretz, F., Westfall, P., 2008. Simultaneous inference in general parametric models. Biom. J. 50, 346-363. 
Jager, T., Klok, C., 2010. Extrapolating toxic effects on individuals to the population level: the role of dynamic energy budgets. Philos. Trans. R. Soc. Lond. B 365, 3531-3540.

Johansson, I., Héas-Moisan, K., Guiot, N., Munschy, C., Tronczyński, J., 2006. Polybrominated diphenyl ethers (PBDEs) in mussels from selected French coastal sites: 1981-2003. Chemosphere, Brominated Flame Retardants (BFRs) in the Environment Papers Presented at the Third International Workshop on Brominated Flame Retardants Held in Toronto, Canada, 6-9 June 2004. Vol. 64, pp. 296-305.

Jørgensen, C., Enberg, K., Mangel, M., 2016. Modelling and interpreting fish bioenergetics: a role for behaviour, life-history traits and survival trade-offs. J. Fish Biol. 88, 389-402.

Kamler, E., 2012. Early Life History of Fish: An Energetics Approach. Springer Science \& Business Media.

Kelly, B.C., Ikonomou, M.G., Blair, J.D., Gobas, F.A.P.C., 2008. Hydroxylated and methoxylated polybrominated diphenyl ethers in a Canadian Arctic marine food web. Environ. Sci. Technol. 42, 7069-7077.

Klok, C., de Roos, A.M., 1996. Population level consequences of toxicological influences on individual growth and reproduction in Lumbricus rubellus (Lumbricidae, Oligochaeta). Ecotoxicol. Environ. Saf. 33, 118-127.

Kooijman, B., 2010. Dynamic Energy Budget Theory for Metabolic Organisation. Cambridge University Press.

Kooijman, S.A.L.M., Metz, J.A.J., 1984. On the dynamics of chemically stressed populations: the deduction of population consequences from effects on individuals. Ecotoxicol. Environ. Saf. 8, 254-274.

Kuiper, R.V., Vethaak, A.D., Cantón, R.F., Anselmo, H., Dubbeldam, M., van den Brandhof, E.-J., Leonards, P.E.G., Wester, P.W., van den Berg, M., 2008. Toxicity of analytically cleaned pentabromodiphenylether after prolonged exposure in estuarine European flounder (Platichthys flesus), and partial life-cycle exposure in fresh water zebrafish (Danio rerio). Chemosphere, Brominated Flame Retardants (BFRs) Papers presented at the Fourth International Symposium, BFR2007, held in Amsterdam, The Netherlands 24-27 April 2007. Vol. 73, pp. 195-202.

Kumaraguru, A.K., Beamish, F.W.H., 1983. Bioenergetics of acclimation to permethrin (NRDC-143) by rainbow trout. Comp. Biochem. Physiol. Comp. Pharmacol. 75, 247-252.

Lasker, R., 1978. The relations between oceanographic conditions and larval anchovy food in the California current: identification of factors contributing to recruitment failure. Rapp. P.-V. Reun. Cons. Int. Explor. Mer 173, 212-230.

Law, R.J., Allchin, C.R., de Boer, J., Covaci, A., Herzke, D., Lepom, P., Morris, S., Tronczynski, J., de Wit, C.A., 2006. Levels and trends of brominated flame retardants in the European environment. Chemosphere, Brominated Flame Retardants (BFRs) in the Environment Papers Presented at the Third International Workshop on Brominated Flame Retardants Held in Toronto, Canada, 6-9 June 2004. Vol. 64, pp. 187-208. 

20.

1033 Leaf, R.T., Friedland, K.D., 2014. Autumn bloom phenology and magnitude influence 1034 haddock recruitment on Georges Bank. ICES J. Mar. Sci. 71, 2017-2025.

1035 Lema, S.C., Schultz, I.R., Scholz, N.L., Incardona, J.P., Swanson, P., 2007. Neural defects 1036 and cardiac arrhythmia in fish larvae following embryonic exposure to 2,2',4,4'1037 tetrabromodiphenyl ether (PBDE 47). Aquat. Toxicol. 82, 296-307.

1038 Letcher, R.J., Gebbink,W.A., Sonne, C., Born, E.W., McKinney, M.A., Dietz, R., 2009.

1039

1040

1041

1042

1043

1044

1045

1046

1047

1048

1049

1050

1051

1052

1053

1054

1055

1056

1057

1058

1059

1060

1061

1062

1063

1064

1065

1066

1067

1068

1069

1070 Bioaccumulation and biotransformation of brominated and chlorinated contaminants and their metabolites in ringed seals (Pusa hispida) and polar bears (Ursus maritimus) from East Greenland. Environ. Int. 35, 1118-1124.

Lusseau, S.M., Gallego, A., Rasmussen, J., Hatfield, E.M.C., Heath, M., 2014. North Sea herring (Clupea harengus L.) recruitment failure may be indicative of poor feeding success. ICES J. Mar. Sci. 71, 2026-2041.

Lyche, J.L., Nourizadeh-Lillabadi, R., Almaas, C., Stavik, B., Berg, V., Skåre, J.U., Alestrøm, P., Ropstad, E., 2010. Natural mixtures of persistent organic pollutants (POP) increase weight gain, advance puberty, and induce changes in gene expression associated with steroid hormones and obesity in female zebrafish. J. Toxic. Environ. Health A 73, 1032-1057.

Lyche, J.L., Nourizadeh-Lillabadi, R., Karlsson, C., Stavik, B., Berg, V., Skåre, J.U., Alestrøm, P., Ropstad, E., 2011. Natural mixtures of POPs affected body weight gain and induced transcription of genes involved in weight regulation and insulin signaling. Aquat. Toxicol. 102, 197-204.

Ma, X., Zhang, H., Yao, Z., Zhao, X., Wang, L., Wang, Z., Chen, Jiping, Chen, Jingwen, 2013. Bioaccumulation and trophic transfer of polybrominated diphenyl ethers (PBDEs) in a marine food web from Liaodong Bay, North China. Mar. Pollut. Bull. 74, 110-115.

Martin, B.T., Jager, T., Nisbet, R.M., Preuss, T.G., Hammers-Wirtz, M., Grimm, V., 2013. Extrapolating ecotoxicological effects from individuals to populations: a generic approach based on dynamic energy budget theory and individual-based modeling. Ecotoxicology 22, $574-583$.

McCarthy, I.D., Fuiman, L.A., Alvarez, M.C., 2003. Aroclor 1254 affects growth and survival skills of Atlantic croaker Micropogonias undulatus larvae. Mar. Ecol. Prog. Ser. 252, 295301.

Metts, B.S., Buhlmann, K.A., Tuberville, T.D., Scott, D.E., Hopkins, W.A., 2013. Maternal transfer of contaminants and reduced reproductive success of southern toads (Bufo [Anaxyrus] terrestris) exposed to coal combustion waste. Environ. Sci. Technol. 47, 28462853.

Miller,M.A., 1993. Maternal transfer of organochlorine compounds in Salmonines to their eggs. Can. J. Fish. Aquat. Sci. 50, 1405-1413.

Mills, L.J., Chichester, C., 2005. Review of evidence: are endocrine-disrupting chemicals in the aquatic environment impacting fish populations? Sci. Total Environ. 343, 1-34. 
1071 Mizukawa, K., Takada, H., Takeuchi, I., Ikemoto, T., Omori, K., Tsuchiya, K., 2009. 1072 Bioconcentration and biomagnification of polybrominated diphenyl ethers (PBDEs) through 1073 lower-trophic-level coastal marine food web. Mar. Pollut. Bull. 58, 1217-1224.

1074 Mollet, F., Kraak, S., Rijnsdorp, A., 2007. Fisheries-induced evolutionary changes in 1075 maturation reaction norms in North Sea sole Solea solea. Mar. Ecol. Prog. Ser. 189-199.

1076 Muir, D., Savinova, T., Savinov, V., Alexeeva, L., Potelov, V., Svetochev, V., 2003. 1077 Bioaccumulation of PCBs and chlorinated pesticides in seals, fishes and invertebrates from 1078 the White Sea, Russia. Sci. Total Environ. 306, 111-131.

1079 Muirhead, E.K., Skillman, A.D., Hook, S.E., Schultz, I.R., 2006. Oral exposure of PBDE-47 1080 in fish: toxicokinetics and reproductive effects in Japanese Medaka (Oryzias latipes) and 1081 fathead minnows (Pimephales promelas). Environ. Sci. Technol. 40, 523-528.

1082 Munns,W.R., Black, D.E., Gleason, T.R., Salomon, K., Bengtson, D., Gutjahr-Gobell, R., 1083 1997. Evaluation of the effects of dioxin and PCBs on Fundulus heteroclitus populations 1084 using a modeling approach. Environ. Toxicol. Chem. 16, 1074-1081.

1085

1086

1087

1088

1089

1090

1091

1092

1093

1094

1095

1096

1097

1098

1099

1100

1101

1102

1103

1104

1105

1106

1107

1108

Munschy, C., Héas-Moisan, K., Tixier, C., Olivier, N., Gastineau, O., Le Bayon, N., Buchet, V., 2011. Dietary exposure of juvenile common sole (Solea solea L.) to polybrominated diphenyl ethers (PBDEs): part 1. bioaccumulation and elimination kinetics of individual congeners and their debrominated metabolites. Environ. Pollut. 159, 229-237.

Nasiadka, A., Clark, M.D., 2012. Zebrafish breeding in the laboratory environment. ILAR J. $53,161-168$.

Newman, M.C., Clements, W.H., 2008. Ecotoxicology: A Comprehensive Treatment. CRC Press, Boca Raton, FL, USA.

Niimi, A.J., 1983. Biological and Toxicologtcal effects of environmental contaminants in fish and their eggs. Can. J. Fish. Aquat. Sci. 40, 306-312.

Nourizadeh-Lillabadi, R., Lyche, J.L., Almaas, C., Stavik, B., Moe, S.J., Aleksandersen, M., Berg, V., Jakobsen, K.S., Stenseth, N.C., Skåre, J.U., Alestrøm, P., Ropstad, E., 2009. Transcriptional regulation in liver and testis associated with developmental and reproductive effects in male zebrafish exposed to natural mixtures of persistent organic pollutants (POP). J. Toxicol. Environ. Health A 72, 112-130.

Nüsslein-Volhard, C., Dahm, R., 2002. Zebrafish: A Practical Approach. Oxford University Press.

Nyholm, J.R., Norman, A., Norrgren, L., Haglund, P., Andersson, P.L., 2008. Maternal transfer of brominated flame retardants in zebrafish (Danio rerio). Chemosphere, Brominated Flame Retardants (BFRs) Papers Presented at the Fourth International Symposium, BFR2007, Held in Amsterdam, The Netherlands 24-27 April 2007. Vol. 73, pp. 203-208.

Nyholm, J.R., Norman, A., Norrgren, L., Haglund, P., Andersson, P.L., 2009. Uptake and biotransformation of structurally diverse brominated flame retardants in zebrafish (Danio rerio) after dietary exposure. Environ. Toxicol. Chem. 28, 1035-1042. 
1109 Nyman, M., Koistinen, J., Fant, M.L., Vartiainen, T., Helle, E., 2002. Current levels of DDT, 1110 PCB and trace elements in the Baltic ringed seals (Phoca hispida baltica) and grey seals 1111 (Halichoerus grypus). Environ. Pollut. 119, 399-412.

1112 Oliveira, M., Gravato, C., Guilhermino, L., 2012. Acute toxic effects of pyrene on 1113 Pomatoschistus Microps (Teleostei, Gobiidae): mortality, biomarkers and swimming 1114 performance. Ecol. Indic. 19, 206-214.

1115 Ôrn, S., Andersson, P.L., Förlin, L., Tysklind,M., Norrgren, L., 1998. The impact on reproduction of an orally administered mixture of selected PCBs in zebrafish (Danio rerio). Arch. Environ. Contam. Toxicol. 35, 52-57.

OSPAR Commission, 2009. OSPAR Background Document on Certain Brominated Flame Retardants - Update 2009. OSPAR Convention for the Protection of the Marine Environment of the North-East Atlantic, London, UK.

OSPAR Commission, 2013. OSPAR List of Chemicals for Priority Action (Revised 2013) (Reference Number 2004-12). p. 8 (London, UK).

Ottersen, G., Hjermann, D.Ø., Stenseth, N.C., 2006. Changes in spawning stock structure strengthen the link between climate and recruitment in a heavily fished cod (Gadus morhua) stock. Fish. Oceanogr. 15, 230-243.

1126 Partridge, L., Sibly, R., Beverton, R.J.H., Hill,W.G., 1991. Constraints in the evolution of life histories. Philos. Trans. R. Soc. B 332, 3-13.

1128 Paull, G.C., Van Look, K.J.W., Santos, E.M., Filby, A.L., Gray, D.M., Nash, J.P., Tyler, C.R., 2008. Variability in measures of reproductive success in laboratory-kept colonies of zebrafish and implications for studies addressing population-level effects of environmental chemicals. Aquat. Toxicol. 87, 115-126.

1132 Péan, S., Daouk, T., Vignet, C., Lyphout, L., Leguay, D., Loizeau, V., Bégout, M.-L., Cousin, X., 2013. Long-term dietary-exposure to non-coplanar PCBs induces behavioral disruptions in adult zebrafish and their offspring. Neurotoxicol. Teratol. 39, 45-56.

1135 Perrin, N., Sibly, R.M., 1993. Dynamic models of energy allocation and investment. Annu. 1136 Rev. Ecol. Syst. 24, 379-410.

1137 Pinheiro, J., Bates, D., 2000. Mixed-Effects Models in S and S-PLUS, Statistics and 1138 Computing. Springer-Verlag, New York.

1139 Pinheiro, J., Bates, D., DebRoy, S., Sarkar, D., Core Team, R., 2016. nlme: Linear and 1140 NonlinearMixed Effects Models. R package version. 3:pp. 1-127. http://CRAN.R1141 project.org/package $=$ nlme.

1142 Pritt, J.J., Roseman, E.F., O'Brien, T.P., 2014. Mechanisms driving recruitment variability in 1143 fish: comparisons between the Laurentian Great Lakes and marine systems. ICES J. Mar. Sci. $114471,2252-2267$.

1145 Pyron, M., 2003. Female preferences and male-male interactions in zebrafish (Danio rerio). 1146 Can. J. Zool. 81, 122-125. 
1147 Rauschenberger, R.H., Wiebe, J.J., Sepúlveda, M.S., Scarborough, J.E., Gross, T.S., 2007. 1148 Parental exposure to pesticides and poor clutch viability in American alligators. Environ. Sci. 1149 Technol. 41, 5559-5563.

1150 Rigét, F., Vorkamp, K., Bossi, R., Sonne, C., Letcher, R.J., Dietz, R., 2016. Twenty years of 1151 monitoring of persistent organic pollutants in Greenland biota. A review. Environmental 1152 Pollution, Persistent Organic Pollutants (POPs): Trends, Sources and Transport Modelling. 1153 217, pp. 114-123.

1154 Riou, P., Le Pape, O., Rogers, S.I., 2001. Relative contributions of different sole and plaice nurseries to the adult population in the Eastern channel: application of a combined method using generalized linear models and a geographic information system. Aquat. Living Resour. $14,125-135$.

Robinson, C.D., Webster, L., Martínez-Gómez, C., Burgeot, T., Gubbins, M.J., Thain, J.E., Vethaak, A.D., McIntosh, A.D., Hylland, K., 2017. Assessment of contaminant concentrations in sediments, fish and mussels sampled from the North Atlantic and European regional seas within the ICON project. Mar. Environ. Res. 124, 21-31 (The ICON Project (the trans European research project on field studies related to a large-scale sampling and 1163 monitoring)).

1164 Rochette, S., Rivot, E., Morin, J., Mackinson, S., Riou, P., Le Pape, O., 2010. Effect of nursery habitat degradation on flatfish population: application to Solea solea in the Eastern Channel (Western Europe). J. Sea Res. 64, 34-44.

1167 Rochette, S., Huret, M., Rivot, E., Le Pape, O., 2012. Coupling hydrodynamic and 1168 individualbased models to simulate long-term larval supply to coastal nursery areas. Fish. 1169 Oceanogr. 21, 229-242.

1170 Russell, R.W., Gobas, F.A.P.C., Haffner, G.D., 1999. Maternal transfer and in Ovo exposure of organochlorines in oviparous organisms: a model and field verification. Environ. Sci. Technol. 33, 416-420.

Singleman, C., Holtzman, N.G., 2014. Growth andmaturation in the zebrafish, danio Rerio: a staging tool for teaching and research. Zebrafish 11, 396-406. theory restores coherence in biology. Philos. Trans. R. Soc. Lond. Ser. B Biol. Sci. 365, 1177 3413-3428.

Spence, R., Smith, C., 2006. Mating preference of female zebrafish, Danio rerio, in relation to male dominance. Behav. Ecol. 17, 779-783.

1180 Stapleton, H.M., Letcher, R.J., Baker, J.E., 2004. Debromination of Polybrominated diphenyl ether congeners BDE 99 and BDE 183 in the intestinal tract of the common carp (Cyprinus carpio). Environ. Sci. Technol. 38, 1054-1061.

1183 Stearns, S.C., 1992. The Evolution of Life Histories. Oxford University Press, New York.

1184 Sun, L., Zuo, Z., Chen, M., Chen, Y., Wang, C., 2015. Reproductive and transgenerational toxicities of phenanthrene on female marine medaka (Oryzias melastigma). Aquat. Toxicol. 162, 109-116. 
1189 Therneau, T.M., Grambsch, P.M., 2000. Modeling Survival Data: Extending the Cox Model. 1190 Springer Science \& Business Media.

1191 Trippel, E., Kjesbu, O., Solemdal, P., 1997. Effects of adult age and size structure on 1192 reproductive output in marine fishes. In: Chambers, R.C., Trippel, E.A. (Eds.), Early Life 1193 History and Recruitment in Fish Populations. Springer, Netherlands, pp. 31-62.

1194 Ungerer, J.R., Thomas, P., 1996. Role of very low density lipoproteins in the accumulation of 1195 o,p'-DDT in fish ovaries during gonadal recrudescence. Aquat. Toxicol. 35, 183-195.

1196 United Nations Environment Programme, 1999. Guidelines for the Identification of PCBs and 1197 Materials Containing PCBs (First issue. Prepared by UNEP Chemicals).

1198 United Nations Environment Programme, 2001. Stockholm Convention on Persistent Organic 1199 Pollutants (2256 UNTS 119; 40 ILM 532).

1200 United Nations Environment Programme, 2012. Draft Guidance for the Inventory of Polybrominated Diphenyl Ethers (PBDEs) Listed under the Stockholm Convention on Persistent Organic Pollutants.

1203

Uusi-Heikkilä, S.,Wolter, C.,Meinelt, T., Arlinghaus, R., 2010. Size-dependent reproductive success of wild zebrafish Danio rerio in the laboratory. J. Fish Biol. 77, 552-569.

Uusi-Heikkilä, S., Kuparinen, A., Wolter, C., Meinelt, T., O'Toole, A.C., Arlinghaus, R., 2011. Experimental assessment of the probabilistic maturation reaction norm: condition matters. Proc. R. Soc. Lond. B Biol. Sci. 278, 709-717.

Vasseur, P., Cossu-Leguille, C., 2006. Linking molecular interactions to consequent effects of persistent organic pollutants (POPs) upon populations. Chemosphere 62, 1033-1042.

Vignet, C., Le Menach, K., Mazurais, D., Lucas, J., Perrichon, P., Le Bihanic, F., Devier, M.H., Lyphout, L., Frère, L., Bégout, M.-L., Zambonino-Infante, J.-L., Budzinski, H., Cousin, X., 2014. Chronic dietary exposure to pyrolytic and petrogenic mixtures of PAHs causes physiological disruption in zebrafish - part I: survival and growth. Environ. Sci. Pollut. Res. $21,13804-13817$.

Vignet, C., Larcher, T., Davail, B., Joassard, L., Le Menach, K., Guionnet, T., Lyphout, L., Ledevin,M., Goubeau,M., Budzinski, H., Bégout,M.-L., Cousin, X., 2016. Fish reproduction is disrupted upon lifelong exposure to environmental PAHs fractions revealing different modes of action. Toxics 4, 26.

Vignet, C., Trenkel, V.M., Vouillarmet, A., Bricca, G., Bégout, M.-L., Cousin, X., 2017. Changes in brain monoamines underlie behavioural disruptions after zebrafish diet exposure to polycyclic aromatic hydrocarbons environmental mixtures. Int. J. Mol. Sci. 18.

Von Bertalanffy, L., 1938. A quantitative theory of organic growth. Hum. Biol. 10, 181-213. 
1223 Voorspoels, S., Covaci, A., Schepens, P., 2003. Polybrominated diphenyl ethers in marine 1224 species from the Belgian North Sea and the western Scheldt estuary: levels, profiles, and 1225 distribution. Environ. Sci. Technol. 37, 4348-4357.

1226 Wright, P.J., 2007. Understanding the maturation process for field investigations of fisheriesinduced evolution. Mar. Ecol. Prog. Ser. 335, 279-283.

1228 Yu, L., Lam, J.C.W., Guo, Y., Wu, R.S.S., Lam, P.K.S., Zhou, B., 2011. Parental transfer of 1229 Polybrominated diphenyl ethers (PBDEs) and thyroid endocrine disruption in zebrafish. 1230 Environ. Sci. Technol. 45, 10652-10659.

1231 Yu, L., Han, Z., Liu, C., 2015. A review on the effects of PBDEs on thyroid and reproduction systems in fish. General and Comparative Endocrinology, Disruption of the Thyroid and Sex Steroid Hormone Systems and Their Crosstalk in Aquatic Wildlife. 219, pp. 64-73.

Zhang, K., Wan, Y., Giesy, J.P., Lam, M.H.W., Wiseman, S., Jones, P.D., Hu, J., 2010. Tissue concentrations of Polybrominated compounds in Chinese sturgeon (Acipenser Sinensis): origin, hepatic sequestration, and maternal transfer. Environ. Sci. Technol. 44, $1237 \quad 5781-5786$ Environmental characteristics of polybrominated diphenyl ethers in marine system, with emphasis on marine organisms and sediments. Biomed. Res. Int. 2016. New York, NY. 


\section{Supplementary material}

Table S1. Diet composition. List of PCB and PBDE congeners used in this work along with the chlorine and bromine numbers. Targeted and measured congeners concentrations (ng g-1 ww) in

detection.

\begin{tabular}{|c|c|c|c|c|c|c|c|c|c|c|}
\hline \multirow{3}{*}{$\begin{array}{c}\text { Congener } \\
\text { CB-8 }\end{array}$} & \multirow{3}{*}{$\frac{\mathrm{Br} / \mathrm{Cl}}{2}$} & \multicolumn{5}{|l|}{ MIX diet } & \multicolumn{4}{|c|}{ SOLV diet } \\
\hline & & \multirow{2}{*}{$\frac{\text { Targeted concentration }\left(\mathrm{ng} \mathrm{g}^{-1}\right)}{28}$} & \multicolumn{3}{|c|}{ Measured concentration $\left(\mathrm{ng} \mathrm{g}^{-1}\right)$} & \multirow{2}{*}{$\begin{array}{c}\text { Spiking efficiency }(\%) \\
97.1\end{array}$} & \multicolumn{3}{|c|}{ Measured concentration $\left(\mathrm{ng} \mathrm{g}^{-1}\right)$} & \multirow{2}{*}{$\frac{\text { Occurrence (n) }}{3}$} \\
\hline & & & 27.20 & \pm & 1.21 & & 0.20 & \pm & 0.05 & \\
\hline CB-18 & 3 & 38 & 32.70 & \pm & 1.37 & 86.1 & 0.60 & \pm & 0.28 & 4 \\
\hline CB-28 & 3 & 75 & 69.00 & \pm & 3.35 & 92 & 0.30 & \pm & 0.07 & 5 \\
\hline CB-31 & 3 & 42 & 47.40 & \pm & 1.74 & 112.9 & 0.30 & \pm & 0.05 & 4 \\
\hline CB-44 & 4 & 65 & 66.50 & \pm & 1.83 & 102.3 & 0.40 & \pm & 0.23 & 4 \\
\hline CB-49 & 4 & 54 & 53.20 & \pm & 4.67 & 98.5 & n.a. & & n.a. & n.a. \\
\hline CB-52 & 4 & 65 & 64.10 & \pm & 2.76 & 98.6 & 0.20 & \pm & 0.04 & 6 \\
\hline CB-77 & 4 & 30 & 31.80 & \pm & 1.54 & 106 & n.a. & & n.a. & n.a. \\
\hline CB-101 & 5 & 150 & 151.90 & \pm & 6.47 & 101.3 & 0.90 & \pm & 0.48 & 8 \\
\hline CB-105 & 5 & 76 & 78.90 & \pm & 5.43 & 103.8 & 0.40 & \pm & 0.18 & 8 \\
\hline CB-110 & 5 & 166 & 170.60 & \pm & 7.03 & 102.8 & 0.60 & \pm & 0.19 & 8 \\
\hline CB-118 & 5 & 110 & 107.30 & \pm & 3.05 & 97.5 & 0.60 & \pm & 0.16 & 8 \\
\hline CB-128 & 6 & 37 & 32.60 & \pm & 1.30 & 88.1 & 0.20 & \pm & 0.07 & 6 \\
\hline CB-132 & 6 & 71 & 68.70 & \pm & 6.46 & 96.8 & 0.20 & \pm & 0.11 & 5 \\
\hline CB-138 & 6 & 207 & 199.60 & \pm & 4.94 & 96.4 & 0.60 & \pm & 0.30 & 8 \\
\hline CB-149 & 6 & 158 & 161.70 & \pm & 2.47 & 102.3 & 0.80 & \pm & 0.24 & 8 \\
\hline CB-153 & 6 & 280 & 270.40 & \pm & 14.24 & 96.6 & 0.60 & \pm & 0.42 & 8 \\
\hline CB-156 & 6 & 38 & 34.10 & \pm & 3.71 & 89.7 & 0.10 & \pm & 0.01 & 7 \\
\hline CB-170 & 7 & 71 & 69.10 & \pm & 4.76 & 97.3 & $<\mathrm{LOD}$ & & - & 8 \\
\hline CB-180 & 7 & 130 & 129.30 & \pm & 5.55 & 99.4 & 0.30 & \pm & 0.12 & 8 \\
\hline CB-187 & 7 & 35 & 32.60 & \pm & 2.91 & 93.1 & 0.60 & \pm & 0.45 & 4 \\
\hline CB-194 & 8 & 35 & 33.60 & \pm & 3.56 & 96 & $<\mathrm{LOD}$ & & - & 4 \\
\hline Sum PCBs & & 1991 & 1932.30 & \pm & 90.35 & 97.05 & 7.90 & & 3.45 & \\
\hline BDE-28 & 3 & 9.95 & 10.78 & \pm & 0.60 & 108.3 & 0.03 & \pm & 0.01 & 5 \\
\hline BDE-47 & 4 & 49.97 & 49.93 & \pm & 2.91 & 99.9 & 0.35 & \pm & 0.13 & 16 \\
\hline BDE-100 & 5 & 14.94 & 15.95 & \pm & 1.19 & 106.8 & 0.09 & \pm & 0.04 & 16 \\
\hline BDE-99 & 5 & 30.25 & 30.25 & \pm & 1.63 & 100.0 & 0.11 & \pm & 0.07 & 16 \\
\hline BDE-153 & 6 & 9.74 & 10.18 & \pm & 0.56 & 104.5 & 0.03 & \pm & 0.004 & 6 \\
\hline BDE-183 & 7 & 100.48 & 130.20 & \pm & 12.65 & 129.6 & 0.14 & & - & 1 \\
\hline BDE-209 & 10 & 195.73 & 232.53 & \pm & 31.27 & 118.8 & 0.17 & \pm & 0.11 & 16 \\
\hline Sum PBDEs & & 411.1 & 479.82 & \pm & 50.81 & 116.7 & 0.92 & \pm & 0.36 & \\
\hline
\end{tabular}




\section{Quality assurance/quality control}

1263

1264

1265

1266

1267

\section{PCB analysis}

The calibration of the system was performed within quite a range using a multi-point (6) calibration curve to define the linearity range of our detector (ECD) for all contaminants, for example from 4 to $2000 \mathrm{pg} . \mu \mathrm{l}^{-1}$ for $\mathrm{CB}-153$. The relative precision of the method was checked for this type of samples by the analysis of 6 aliquots of a homogeneous preparation of fish (laboratory control card). The results showed coefficients of variation of less than $10 \%$ for all congeners, which indicates a satisfactory reproducibility of the method. During the analysis of the real samples, analytical blanks were systematically measured every 10 samples. The blank were about $0.2 \mathrm{pg} . \mu \mathrm{l}^{-1}, 20$ times less than the concentrations of the lowest standard of CB-153

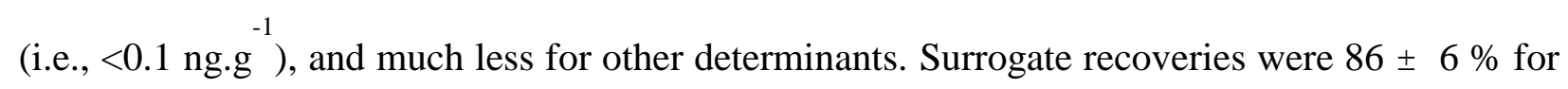
CB-30, $97 \pm 8 \%$ for CB-198 and $102 \pm 9 \%$ for CB-209 (mean \pm SD calculated on $\mathrm{n}=93$ analyses) and no surrogate correction was applied for the reported concentrations.

Finally, 6 replicates of a Standard Reference Material, SRM2977 (mussel tissue) were analysed in order to determine the accuracy and precision of the method. PCB recoveries varied between 77 and $115 \%$. The concentrations of the real samples were not corrected for recoveries. Moreover, the RSD values ranged from 3.8 to $19.6 \%$, with a mean of $9.7 \%$ for all PCBs. All these results were in agreement with certified reference.

The limit of quantification (LOQ) was estimated taking into account a signal to noise ratio of 3 , the injection volume $(1 \mu \mathrm{l})$, the volume of the concentrated extract before injection $(250 \mu \mathrm{l})$ and the extracted sample mass. Average value varied between 2 to $15 \mathrm{pg}$ depending to congener.

\section{PBDE analysis}


1285 Quality Assurance / quality Control procedures were implemented for each batch of 8 to 10

1286 samples, including procedural blanks, use of recovery surrogates in all samples, analysis of 1287 certified reference material and participation to inter-comparison exercises. Detailed information 1288 can be found in Munschy et al. (2011) and an update is given below.

1289 Procedural blank samples were analysed in every batch of 8 to 10 samples using glass powder, 1290 extracted and processed in the same manner as the fish samples. Blanks were contamination-free, 1291 with the exception of BDE-209, which was found at $0.5 \pm 0.3 \mathrm{pg}$ injected (average value 1292 calculated on 14 blanks). BDE-209 concentrations were corrected from blank values in every 1293 sample. The values obtained in each blank were used to correct the values in samples analysed in 1294 the same batch.

1295 The limit of quantification (LOQ) was calculated for each sample taking into account a signal to 1296 noise ratio of 3 , the injection volume, the volume of the concentrated extract before injection and 1297 the extracted sample mass. Average value was $0.09 \pm 0.05 \mathrm{ng} \mathrm{g}^{-1} \mathrm{ww}(\mathrm{n}=93)$.

1298 Surrogate recoveries were $88 \pm 8 \%$ for BDE-139 and $77 \pm 17 \%$ for ${ }^{13} \mathrm{C}$ BDE-209 (mean \pm SD 1299 calculated on $\mathrm{n}=93$ analyses) and no surrogate correction was applied for the reported 1300 concentrations.

1301 Certified reference material (WMF-01, supplied by Wellington laboratories Inc., Ontario, 1302 Canada) was routinely included in each sequence of samples and the results were within \pm 2 1303 times the standard deviations of the means of the certified values. WMF-01 consists of a freeze1304 dried fish sample for which certified or indicative values are given for 7 congeners (namely, 1305 BDE-28, BDE-47, BDE-99, BDE-100, BDE-153, BDE-154, BDE-183) at concentrations of 1306 between $0.53 \pm 0.40 \mathrm{ng} \mathrm{g}^{-1}$ dry weight $(\mathrm{dw})$ for BDE-183 and $123.2 \pm 24.8 \mathrm{ng} \mathrm{g}^{-1} \mathrm{dw}$ for BDE130747.

1308 The laboratory regularly takes part in Quality Assurance of Information for Marine 1309 Environmental Monitoring in Europe (QUASIMEME) inter-comparison exercises for PBDEs in 
1310 biota and our Z-scores are satisfactory, i.e., between - 2 and +2 (for example, they were between $1311-0.28$ and -0.77 in 2015 and between -0.83 and +0.32 in 2016). 


\begin{tabular}{|c|c|c|c|c|c|c|c|c|c|c|c|c|}
\hline & & & & & & & & \multirow{2}{*}{\multicolumn{2}{|c|}{ Growth monitoring }} & \multirow{2}{*}{\multicolumn{3}{|c|}{ Reproduction monitoring }} \\
\hline \multirow[b]{3}{*}{ Replicates } & \multirow{3}{*}{ Birth date } & & & \multicolumn{4}{|c|}{ Survival monitoring } & & & & & \\
\hline & & \multicolumn{2}{|c|}{ Number of tanks } & \multicolumn{2}{|c|}{ Early } & \multicolumn{2}{|c|}{ Juvenile/adult } & \multirow{2}{*}{$\begin{array}{l}\text { Number of } \\
\text { biometries }\end{array}$} & \multirow{2}{*}{$\begin{array}{l}\text { Ages (dpf) at } \\
\text { biometry }\end{array}$} & \multirow{2}{*}{$\begin{array}{l}\text { Starting date } \\
\text { (age in dpf) }\end{array}$} & \multirow[b]{2}{*}{ End date } & \multirow[b]{2}{*}{ Duration (days } \\
\hline & & SOLV & $\overline{M I X}$ & $\begin{array}{l}\text { Starting date } \\
(5 \mathrm{dpf})\end{array}$ & \begin{tabular}{|c}
$\begin{array}{c}\text { End date } \\
\text { (age in dpf) }\end{array}$ \\
\end{tabular} & $\begin{array}{l}\text { Starting date } \\
\text { (age in dpf) }\end{array}$ & $\begin{array}{c}\text { End date } \\
\text { (age in dpf) }\end{array}$ & & & & & \\
\hline $\mathrm{R} 1$ & $19 / 02 / 2014$ & 10 & 10 & $24 / 02 / 2014$ & $\begin{array}{c}30 / 03 / 2014 \\
(39)\end{array}$ & $\begin{array}{c}30 / 03 / 2014 \\
(39)\end{array}$ & $\begin{array}{c}28 / 08 / 2014 \\
(190)\end{array}$ & 5 & $\begin{array}{c}63,96,135,160 \\
190\end{array}$ & $\begin{array}{c}13 / 05 / 2014 \\
(83) \\
\end{array}$ & $06 / 06 / 2014$ & 13 \\
\hline $\mathrm{R} 2$ & $12 / 03 / 2014$ & 8 & 8 & $17 / 03 / 2014$ & $\begin{array}{c}12 / 04 / 2014 \\
(31)\end{array}$ & $\begin{array}{c}12 / 04 / 2014 \\
(31)\end{array}$ & $\begin{array}{c}\text { 09/09/2014 } \\
(181)\end{array}$ & 4 & $82,119,147,181$ & $\begin{array}{c}21 / 05 / 2014 \\
(70) \\
\end{array}$ & $19 / 06 / 2014$ & 14 \\
\hline R3 & $01 / 10 / 2014$ & 9 & 8 & $06 / 10 / 2014$ & $\begin{array}{c}26 / 10 / 2014 \\
(25)\end{array}$ & $\begin{array}{l}26 / 10 / 2014 \\
(25)\end{array}$ & $\begin{array}{c}\text { 30/03/2015 } \\
\quad(180)\end{array}$ & 11 & $\begin{array}{c}57,97,127,149, \\
180,210,240, \\
268,302,335, \\
362 \\
\end{array}$ & - & - & - \\
\hline $\mathrm{R} 4$ & $26 / 11 / 2014$ & 10 & 10 & $01 / 12 / 2014$ & $\begin{array}{c}19 / 12 / 2014 \\
(23)\end{array}$ & $\begin{array}{c}19 / 12 / 2014 \\
(23)\end{array}$ & $\begin{array}{c}27 / 05 / 2015 \\
(182)\end{array}$ & 5 & $\begin{array}{c}61,90,120,182, \\
211\end{array}$ & $\begin{array}{c}27 / 01 / 2015 \\
(62) \\
\end{array}$ & $11 / 03 / 2015$ & 25 \\
\hline R5 & $01 / 04 / 2015$ & 10 & 10 & $06 / 04 / 2015$ & $\begin{array}{c}03 / 05 / 2015 \\
(32)\end{array}$ & $\begin{array}{c}03 / 05 / 2015 \\
(32)\end{array}$ & $\begin{array}{l}28 / 09 / 2015 \\
(180)\end{array}$ & 7 & $\begin{array}{c}64,90,120,150, \\
180,215,244 \\
\end{array}$ & - & - & \\
\hline
\end{tabular}




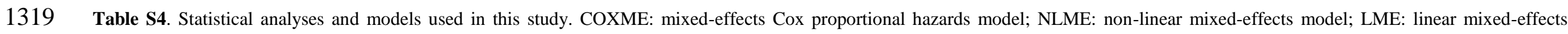

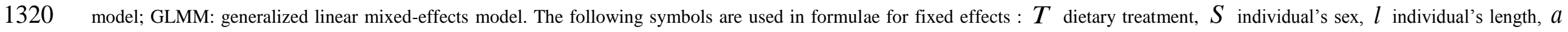

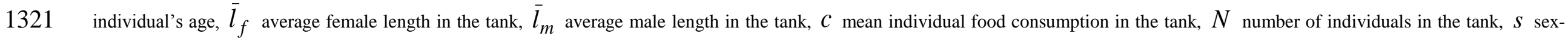
1322 ratio in the tank, $O$ number of the spawning event.

\begin{tabular}{|c|c|c|c|c|c|c|c|c|c|c|}
\hline Generation & Function & Trait & Replicate & Model & Distribution & $\begin{array}{l}\text { Link } \\
\text { function }\end{array}$ & $\begin{array}{l}\text { Variable } \\
\text { transformation }\end{array}$ & Formula (fixed-effects) & Random effects & $\begin{array}{l}\text { Random effects } \\
\text { sources }\end{array}$ \\
\hline F0 & Survival & Early death rate & All & COXME & $\begin{array}{l}\text { Semi- } \\
\text { parametric }\end{array}$ & $\log$ & Identity & $T$ & Intercept & replicate/tank \\
\hline F0 & Survival & $\begin{array}{l}\text { Juvenile/adult death } \\
\text { rate }\end{array}$ & All & COXME & $\begin{array}{l}\text { Semi- } \\
\text { parametric }\end{array}$ & $\log$ & Identity & $T$ & Intercept & replicate \\
\hline F0 & Growth & Initial length $l_{0}$ & All & NLME & Gaussian & Identity & Identity & $T$ & Intercept & replicate/tank \\
\hline F0 & Growth & Growth rate $k$ & All & NLME & Gaussian & Identity & Identity & $S+T+S \times T$ & Intercept & replicate/tank \\
\hline F0 & Growth & Asymptotic length $l_{\infty}$ & All & NLME & Gaussian & Identity & Identity & $S+T+S \times T$ & Intercept & replicate/tank \\
\hline F0 & Condition & Weight & All & LME & Gaussian & Identity & $\log$ & $\begin{array}{l}S+T+S \times T+\log (l)+ \\
\log (l) \times T+\log (l) \times S\end{array}$ & Intercept & replicate/tank \\
\hline F0 & Reproduction & Spawning probability & $\begin{array}{l}\mathrm{R} 1, \mathrm{R} 2, \\
\mathrm{R} 4\end{array}$ & GLMM & Binomial & Logit & Identity & $a+\bar{l}_{f}+\bar{l}_{m}+c+T+T \times a$ & $\begin{array}{l}\text { Intercept and slope } \\
(a+T)\end{array}$ & replicate/tank \\
\hline F0 & Reproduction & Number of eggs & $\begin{array}{l}\mathrm{R} 1, \mathrm{R} 2, \\
\mathrm{R} 4\end{array}$ & LME & Gaussian & Identity & $\begin{array}{l}\text { Box-Cox } \\
(\lambda=0.3)\end{array}$ & $a+c+N+s+T+T \times a$ & $\begin{array}{l}\text { Intercept and slope } \\
(a+T)\end{array}$ & replicate/tank \\
\hline F0 & Reproduction & Fertilization rate & $\begin{array}{l}\mathrm{R} 1, \mathrm{R} 2, \\
\mathrm{R} 4\end{array}$ & GLMM & Binomial & Logit & Identity & $a+\bar{l}_{f}+\bar{l}_{m}+c+T+T \times a$ & $\begin{array}{l}\text { Intercept and slope } \\
(a+T)\end{array}$ & replicate/tank \\
\hline $\mathrm{F} 1$ & $\begin{array}{l}\text { Larval } \\
\text { survival }\end{array}$ & Larval death rate & $\mathrm{R} 4$ & COXME & $\begin{array}{l}\text { Semi- } \\
\text { parametric }\end{array}$ & $\log$ & Identity & $O+T+T \times O$ & Intercept & tank/clutch \\
\hline
\end{tabular}


Table S5. Random effects testing using Likelihood Ratio Test (LRT).

\begin{tabular}{|c|c|c|c|c|c|c|c|}
\hline Generation & Function & Trait & Random effects & $\begin{array}{l}\text { Random effects } \\
\text { sources }\end{array}$ & $d f$ & $\chi^{2}$ & $p$-value \\
\hline \multirow{3}{*}{ F0 } & \multirow{2}{*}{ Survival } & \multirow{2}{*}{$\begin{array}{l}\text { Early death } \\
\text { rate }\end{array}$} & \multirow{2}{*}{ Intercept } & Replicate & 1 & 82.53 & $<0.001$ \\
\hline & & & & Replicate/tank & 1 & 21.11 & $<0.001$ \\
\hline & Survival & $\begin{array}{l}\text { Juvenile/adult } \\
\text { death rate }\end{array}$ & Intercept & Replicate & 1 & 259.79 & $<0.001$ \\
\hline \multirow{6}{*}{ F0 } & \multirow{2}{*}{ Growth } & \multirow{2}{*}{$l_{0}$} & \multirow{2}{*}{ Intercept } & Replicate & 1 & 37.57 & $<0.001$ \\
\hline & & & & Replicate/tank & 1 & 107.68 & $<0.001$ \\
\hline & \multirow{2}{*}{ Growth } & \multirow{2}{*}{$k$} & \multirow{2}{*}{ Intercept } & Replicate & 1 & 99.02 & $<0.001$ \\
\hline & & & & Replicate/tank & 1 & 8.76 & 0.003 \\
\hline & \multirow{2}{*}{ Growth } & \multirow{2}{*}{$l_{\infty}$} & \multirow{2}{*}{ Intercept } & Replicate & 1 & 4.54 & $\mathbf{0 . 0 3 3}$ \\
\hline & & & & Replicate/tank & 1 & 60.28 & $<0.001$ \\
\hline \multirow{2}{*}{ F0 } & \multirow{2}{*}{ Condition } & \multirow{2}{*}{$W$} & \multirow{2}{*}{ Intercept } & Replicate & 1 & 100.24 & $<0.001$ \\
\hline & & & & Replicate/tank & 1 & 243.18 & $<0.001$ \\
\hline \multirow{2}{*}{ F0 } & \multirow{2}{*}{ Reproduction } & \multirow{2}{*}{$\begin{array}{l}\text { Spawning } \\
\text { probability }\end{array}$} & \multirow{2}{*}{$\begin{array}{l}\text { Intercept and } \\
\text { slope }(a+T)\end{array}$} & Replicate & 6 & 1.06 & 0.983 \\
\hline & & & & Replicate/tank & 6 & 32.65 & $<0.001$ \\
\hline \multirow{2}{*}{ F0 } & \multirow{2}{*}{ Reproduction } & \multirow{2}{*}{$\begin{array}{l}\text { Number of } \\
\text { eggs }\end{array}$} & \multirow{2}{*}{$\begin{array}{l}\text { Intercept and } \\
\text { slope }(a+T)\end{array}$} & Replicate & 6 & 3.51 & 0.742 \\
\hline & & & & Replicate/tank & 6 & 16.27 & 0.012 \\
\hline \multirow{2}{*}{ F0 } & \multirow{2}{*}{ Reproduction } & \multirow{2}{*}{$\begin{array}{l}\text { Fertilization } \\
\text { rate }\end{array}$} & \multirow{2}{*}{$\begin{array}{l}\text { Intercept and } \\
\text { slope }(a+T)\end{array}$} & Replicate & 6 & 66.39 & $<0.001$ \\
\hline & & & & Replicate/tank & 6 & 6150.70 & $<0.001$ \\
\hline \multirow{2}{*}{ F1 } & \multirow{2}{*}{$\begin{array}{l}\text { Larval } \\
\text { survival }\end{array}$} & \multirow{2}{*}{$\begin{array}{l}\text { Larval death } \\
\text { rate }\end{array}$} & \multirow{2}{*}{ Intercept } & Tank & 1 & 334.48 & $<0.001$ \\
\hline & & & & Tank/clutch & 1 & 1007.20 & $<0.001$ \\
\hline
\end{tabular}

